\title{
The Victim as Criminal: A Consideration of California's Prostitution Law
}

\author{
M. Anne Jenningst
}

In this Comment the author examines the causes of prostitution and the rationales for retaining its criminal status. She concludes that the attempt to suppress prostitution through the criminal law has not succeeded because of the strong social, economic, and psychological pressures that foster and perpetuate such activity. Finally, on a statutory level, she analyzes current legislative efforts at reform and offers alternative legislation; on a constitutional level, she argues for more active judicial supervision of law enforcement practices in this field to ensure greater protection of individual rights.

All acts of prostitution and solicitation are presently criminal offenses in California. ${ }^{1}$ Increasing public concern over rising crime rates and the rising costs of law enforcement and the administration of justice have caused some observers to question "whether we, the public, are not asking the system of criminal law and justice to do too inuch." ${ }^{2}$ In

$\dagger$ B.A. 1965, M.A. 1966, University of California, Berkeley; third-year student, Boalt Hall School of Law.

1. Cax. Penaz Code $\$ 647$ (West 1970), Disorderly Conduct, provides in part: Every person who commits any of the following acts shall be guilty of

disorderly conduct, a misdeineanor:

-...

(b) Who solicits or who engages in any act of prostitution. As used in

this subdivision, 'prostitution' includes any lewd act between persons for inoney or other consideration.

The maximum penalty is 6 months in jail and a $\$ 500$ fine. This statute replaced the forner vagrancy statute; see notes 27-31 infra and accompanying text. The prostitution laws of other jurisdictions are compared in the appendix to Rosenbleet \& Pariente, The Prostitution of the Criminal Law, 11 AM. CRnM. L. REv. 373, 422 (1973). Thirty-eight states outlaw acts of prostitution, 44 states prohibit solicitation for prostitution, and six states punish the status of being a prostitute under vagrancy laws. See id.

2. San Francisco Committee on Crime, a Report on Non-Victam Crimb in SAN Francisco: Part II, at 1 (1971) [hereinafter cited as S.F. Committeg on CRIME]. The San Francisco Committee on Crime, a blue-ribbon citizens committee, was appointed by Joseph Alioto after his election as mayor in 1968 to study and report on various aspects of crime and criminal justice in the city. The Committee was chaired by prominent attorneys Moses Lasky and William Orrick, and its executive director was Irving Reichert, now General Counsel to the San Francisco Bar Association. The Committee prepared reports on the police, the probation department, the district attorney, the public defender, the sheriff, and the jails in addition to the nonvictim crime 
particular, attention has been drawn toward the area of "victimless" crimes, those crimes in which an attempt to enforce moral norms replaces the protection of complaining victims as the primary impetus for the law. ${ }^{3}$ Prostitution in many respects is a "victimless" crime, in that it often is a private transaction between willing participants. When other crimes occur in association with it, or the openness of solicitation comes to public attention, it may lose its victimless character. Yet the law at present does not draw such distinctions.

The formation of organizations opposed to present prostitution laws ${ }^{4}$ and recent cases challenging the constitutionality of Califormia's prostitution laws ${ }^{5}$ have created a climate appropriate for a reappraisal of our efforts to control prostitution through the criminal law. The recent removal of criminal penalties from noncominercial sexual behavior between consenting adults ${ }^{6}$ further suggests that reappraisal is necessary.

report. Most of its recommendations have yet to be implemented. On the problem of excessive use of the criminal law, see Kadish, The Crisis of Overcriminalization, 374 AnNals 157 (1967) [hereinafter cited as Kadish]; Bilek, America's Criminal Justice System-A Diagnosis and Prognosis, in The Change Process in Cruminal Justice 85 (U.S. Dep't of Justice 1973); H. PACKer, The Lmirts of the Cruminal SANCtIon (1968).

3. See, e.g., H. Packer, The Limits of thi Cruminal Sanction (1968); E. Schur, Crumes Wrthout Victims: Deviant Behavior and Public Policy (1965); Kadish, supra note 2; Skolnick, Coercion to Virtue: The Enforcement of Morals, 41 S. CaL. L. REv. 588 (1968) [hereinafter cited as Coercion to Virtue]. Such crimes include gambling, drug abuse, and private consensual sexual behavior, but not offenses such as indecent exposure or child molestation, which have unwilling victims.

4. An example is San Francisco's C.O.Y.O.T.E. (Cast Off Your Old Tired Ethics), formed by Margo St. James in 1973. A list of such organizations appears in J. James, J. Withers, M. Haft \& S. Theiss, The Polittics of Prostrtution 73-81 (1976) [hereinafter cited as Politics of Prostrtution].

5. Successful challenges have been brought on equal protection grounds in several California cases. People v. Superior Court (Hartway), 56 Cal. App. 3d 608, 128 Cal. Rptr. 519 (1st Dist.), hearing granted, 58 Cal. App. 3d 67 (1976) (subsequent history table); Riemer v. Jensen, No. 455371-9 (Alameda County Super. Ct., Apr. 1, 1975); People v. Richardson, No. M48961 (S.F. Mun. Ct., Oct. 4, 1975). But see In re Elizabeth G., 53 Cal. App. 3d 725, 126 Cal. Rptr. 118 (3d Dist. 1975).

Richardson is presently on appeal. Challenges in other jurisdictions have generally not been successful in modifying laws and enforcement practices. See, e.g., Morgan v. City of Detroit, 389 F. Supp, 922 (E.D. Mich. 1975); United States v. Wilson, 342 A.2d 27 (D.C. App. 1975); United States v. Moses, 339 A.2d 46 (D.C. App. 1975); Moore v. State, 231 Ga. 218, 201 S.E.2d 146 (1973); Wilson v. State, 258 Ind. 3, 278 N.E.2d 569 (1972), cert. denied, 408 U.S. 928 (1974); Cherry v. State, 18 Md. App. 252, 306 A.2d 634 (1973); State v. Mertes, 60 Wis. 2d 414, 210 N.W.2d 741 (1973); but see State v. Fields, No. 72-4788 Cr. (3d Jud. Dist. Alas., June 27, 1973), 13 Crim. L. ReP. 2376; State v. Woods, No. 443012 (Minneapolis Mun. Ct., Dec. 21, 1971).

6. Ch. 71, §§ 1-12, [1975], Cal. Laws Reg. Sess. (2 West CAL. Leo. Serv. 1975), amending and repealing various provisions of the Education, Evidence, and Penal Codes (effective Jan. 1, 1976). Penal Code sections 269a, 269b, 286.1, and 288b, dealing with sodomy and oral copulation, were repealed. These acts remain criminal when they are accompanied by force or are committed on a person under 18 . Two bills were recently introduced in the legislature to decriminalize soine forms of prostitution. See text accompanying notes 142-70 infra for analysis of these bills. 
Any attempt to control prostitution through the criminal law imvolves judgments about the kind and degree of harm it creates, the weighing of the costs of control against the benefits to be gained, and the balancing of competing state and individual interests, primarily tasks for the legislature. Part I of this Comment will address these questions in the following nanner. After a brief examination of the history and nature of prostitution in America, the validity of the rationales for the present law against prostitution will be examined, drawing froin empirically based studies of the problem. The causes of prostitution will then be discussed, with an eye to determining the extent to which it is susceptible to control through the criminal law. Next, the benefits of controlling prostitution will be weighed against the costs of enforcement. Finally, some suggestions for reform will be offered.

Although the legislature has the primary responsibility for determining the means by which society will continue to use the law to control prostitution, existing legislation and enforcement inust conform to evolving constitutional principles. Courts have been and will continue to be called upon to measure existing law against these principles. Part II of this Comment will attempt to elucidate two general constitutional bases on which the law and its enforcement have been challenged: whether the law represents an impermissible intrusion into individual privacy rights and whether current enforcement practices violate fourth amendment standards and the equal protection of the laws. Some attention will also be given to the scope and method of judicial intervention in the event constitutional principles are found to be violated.

\section{I}

\section{Legislative Policy and Social Reality}

As a prerequisite to any atteinpt to determine whether and to what extent a particular form of conduct should be controlled through the criminal law, we must investigate the nature of this conduct. Before exploring the rationales that have been offered for applying criminal sanctions to prostitution, therefore, we will briefly examine the nature of prostitution and the contexts in which it occurs.

\section{A. The Nature of Prostitution}

\section{An Historical Overview}

In its modern usage the term "prostitution" refers to the exchange of sexual services for money. " The demand for prostitutes' services

7. See Cal. Penal Code $\$ 647$ (b) (West 1970), reproduced in part at note 1 supra. An older definition is "the practice of a female offering her body to indiscriminate sexual intercourse with men." 63 AM. JUR. 2d Prostitution $\$ 1$ (1972). 
comes primarily from men, and this demand is largely heterosexual in nature. ${ }^{8}$ The women who supply this demand do so in a variety of contexts, and the structure of the occupation has changed as a result of social and economic changes.

Although prostitution existed to some degree in the colonial and pre-Civil War periods, ${ }^{\theta}$ not until the industrialization, the westward expansion, and the influx of immigrants that followed the Civil War did prostitution become entrenched in this country. ${ }^{10}$ The social confusion that attended these changes, principally the breakdown of the agrarian moral code and the presence in industrial cities and western towns of large numbers of men without families, coincided with the immigration of women from both Europe and rural Anerica. As the demand for prostitutes' services increased, low wages and poor working conditions provided an incentive for women to meet this demand. ${ }^{11}$ Brothels soon became a feature of most American cities.

In the period following the Civil War, two movements emerged with widely divergent views on how to deal with prostitution and the crime and venereal disease that attended its spread. ${ }^{12}$ One group was composed of the "purity crusaders." This complex movement ${ }^{13}$ represented a fusion of the old abolitiomists and the awakening women's movement. This movement, which later recruited those who opposed the use of alcoholic beverages into its ranks, saw in the abolition of prostitution a "new abolitionism" that could serve as a vehicle for the moral reforin of society. ${ }^{14}$ The second group, composed of nembers of the medical profession and the police, responded to the explosion of prostitution with the advocacy of the European nodel of "reglementa-

8. Although male prostitutes exist in many cities, female heterosexual prostitution is far more common. Women account for perhaps 90 percent of the prostitute population. Rosenbleet \& Pariente, supra note 1, at 396, citing Sherwin \& Winick, Debate: Should Prostitution be Legalized?, in SexuAL BeHAvor (Jan. 1972). See also C. Winick \& P. KINSIE, The LIVEly COMMERCE $89-96$ (1973) thereinafter cited as WINICK]. Unless otherwise indicated, the use of the term "prostitution" in this Comment refers to heterosexual prostitution.

9. D. Pivar, Purity Crusade: Sexunl Morality and Social Control, 18681900 at 9, 20 (1973) [hereinafter cited as PrVAR]; V. Bullough, THE History of Prostrtution, 187-90 (1964) [hereinafter cited as Bullough].

10. BulloUGH, supra note 9, at 192 (noting the correlation between the nationality of women arrested as prostitutes and patterns of inmigration); PrVAR, supra note 9, at 9.

11. See Bullougr, supra note 9, at 175 (noting that the immediate effect of the Factory Acts in Britain was to incrense the numbers of women and children available for prostitution).

12. PIVAR, supra note 9, at 32.

13. See generally id.

14. Id. at 33-34. 
tion," a model of enforcement that sought control of prostitution largely for the purpose of preventing venereal disease. ${ }^{15}$

In their struggle to stamp out prostitution, the purity reformers waged an extensive propaganda battle, largely responsible for the characterization of the prostitute as a "fallen woman" recruited by "vice lords" through an extensive white slave traffic. ${ }^{16}$ Allying themselves with the Progressive movement, they achieved apparent victories against the reglenientationists in the period immediately surrounding the First World War. The Federal White Slave Act $^{17}$ was passed in 1910; vice commissions were formed in virtually every city and brothels were closed through the use of red light abatement laws that provided for citizen complaints; ${ }^{18}$ street solicitation, pandering, procuring, and other related practices were outlawed in most states. ${ }^{19}$ These victories proved to be shortlived, however. Prostitution continued in the period between the two World Wars, often accompanied by an unofficial policy of reglementation or "segregation," in which brothels were tolerated in "red light districts" and lieavily repressed elsewhere. ${ }^{20}$

Prostitution flourished around military bases during World War II, again encouraged by the presence of large numbers of men deprived of more conventional relationships and by the general loosening of morals characteristic of wartime. Prostitution persisted in the postwar period, but as a result of efforts at suppression that had begun in the thirties, the organized brothel by now has virtually disappeared. ${ }^{21}$

15. Id. at 28.

16. There is some question as to the extent of the "white slave traffic" in this country. "The Mann Act was passed after there had been many extensive governmental investigations. Yet there was no common understanding of the facts and whatever understanding seems to have been achieved concerning the white slave trade in retrospect seems incorrectly based." E. LeVI, AN INTRODUCTION TO LEGAL REASONING 28 (1949). The hyperbole apparent in his quotations from the Congressional Debates supports this conclusion. Id. at 27-28. Despite its appellation as the White Slave Traffic Act, as Justice Stone noted, "Congress set out im the Mann Act to deal with cases which frequently, if not normally, involve consent and agreement on the part of the woman to the forbidden transportation." Gebardi v. Umited States, 287 U.S. 112, 121 (1932). The image dies hard, however. One California judge remarked recently that "[s]ome of the sordid aspects of the commercial exploitation of prostitutes are too well known to require the citation of any authority. The term 'white slavery' was applied to such exploitation and traffic with good reason." Williams v. Superior Ct., 30 Cal. App. 3d 8, 11, 106 Cal. Rptr. 89, 91 (1st Dist. 1973). The facts of the case, as reported in the opinion, do not appear to have involved coercion, however.

17. 18 U.S.C. $\$ \$ 2421-2424$ (1971) (origmally enacted as Act of June 25, 1910, ch. 395, §§ 1, 2, 5, 8, 36 Stat. 825-27). See note 16 supra.

18. See George, Legal, Medical and Psychiatric Considerations in the Control of Prostitution, 60 Mrch. L. Rev. 717, 734-35 (1962) [hereinafter cited as George].

19. George cites examples of statutes then in existence throughout the country. Id. at $719-30$.

20. Id. at 717; S.F. COMMTTTEE ON CRMME, supra note 2, at 16-18.

21. S.F. COMMITTe ON CRIME, supra note 2, at 16-18. See also Esselstyn, Prostitution in the United States, 376 ANNAzs 123 (1968) [hereinafter cited as Esselstyn]. 


\section{The Discreet and Public Practice of Modern Prostitution}

As a consequence both of laws designed to suppress prostitution and of changing social conditions, a variety of ways of plying the trade has for the most part supplanted the brothel. Many of these forms of prostitution are more discreet than their predecessor, yet the distinction between discreet and public prostitution and the differing problems each creates are not reflected in the current law. ${ }^{22}$

Least likely to come to public attention, because they operate most discreetly, are call girls. ${ }^{23}$ Catering to an affluent chentele, they entertain busimessmen and their associates, conventioneers, and other regular clients. Because of the circumspection with which they operate, access to this type of prostitution is difficult without an "inside" contact. Prostitutes and clients without such access must therefore resort to more open ways of contacting one another. Some prostitutes and their customers, for example, make contact in bars and after-hours clubs, a practice with limited impact on the general public.

Such discreet forms of prostitution are less likely to come to public attention than the activities of streetwalkers, who seek customers with varying degrees of opelmess and take them to nearby motels and hotels. A recent development is the proliferation of massage parlors, in which patrons may receive various sexual services in addition to the legitimato services provided by the establishment. Although massage parlors do not create the kind of public offense that may be created by streetwalkers, the "public" nature of the establishment focuses attention on the illegitimate activities that may take place within..$^{2 \cdot t}$

Although prostitution has been characterized as a victimless crime, the potential for public offense created by the activities of highly visible and aggressive streetwalkers, as well as the occasional association of street prostitution with other crimes, belies this characterization. ${ }^{25}$ Any attempt to control prostitution through the law must take into account its complexities-the differing kinds of problems presented by its different forms.

\section{B. The Rationales for Criminalization}

Prostitution and solicitation per se were not outrawed in California until 1961. Early in its history, California enacted laws proscribing

22. See notes 75-78 infra and accompanying text.

23. See generally M. Stein, Lovers, FrIendS, Slaves (1975) [hereinafter cited as STEIN], a study of New York call girls with emphasis on their clients.

24. For reaction in one California community, see Oakland Tribune, Nov. 13, 1975 , at 1 , col. 5 .

25. S.F. COMMTTEE ON CRIME, supra note 2, at 27-28. 
practices associated with prostitution, ${ }^{26}$ while punishing the "common prostitute" under a vagrancy statute. ${ }^{27}$ Questions about the constitutionality of such "status" offenses ${ }^{28}$ resulted in the repealing of the vagrancy law, ${ }^{29}$ which was replaced by proscriptions on various acts, among them prostitution and solicitation, under the rubric of disorderly conduct. As presently amended, Penal Code section $647(\mathrm{~b})$ states that a person is guilty of disorderly conduct

Who solicits or who engages in any act of prostitution. As used in this subdivision, "prostitution" includes any lewd act between persons for money or other consideration. ${ }^{30}$

Contemporary commentaries on the enactment of section $647(\mathrm{~b})$ offer hittle guidance regarding the legislative purposes behind the criminalization of prostitution and solicitation; ${ }^{31}$ however, several reasons have been advanced by those favoring criminalization.

26. See, e.g., CaL. Penal Code $\$ \$ 266$ (imveiglement or enticement of unmarried female under 18 for prostitution; procuring female for illicit intercourse under false pretences) (enacted 1872); 266a (abduction or procurement by fraudulent inducement), $266 \mathrm{~b}$ (abduction to live in illicit relationship), 266d (receiving money for placing female in custody for purposes of cohabitation), 266e (purchasing female for purposes of prostitution or placing her for immoral purposes), 266f (sale of female for iminoral purposes), $266 \mathrm{~g}$ (placing or permitting placement of wife in house of prostitution), $266 \mathrm{~h}$ (pimping), 266i (pandering), 267 (abduction of female under 18 for purposes of prostitution), 273e (minors not to deliver messages to places of questionable repute), $273 f$ (sending minors to immoral places) (all enacted 1893); 309 (admitting or keeping minors in house of prostitution), 315 (keeping or residing in house of ill-fame), 316 (keeping disorderly houses which disturb peace), 318 (prevailing upon person to visit places of gambling or prostitution) (all enacted 1872) (West 1970). These laws were amended to be gender neutral as of Jan. 1, 1976. As most of these laws proscribe acts involving coercion, they would not be affected by the decrimmalization of prostitution itself. The Red Light Abatement Law, Cal. Penal Code $\$ \S 11225-35$ (enacted 1913) (West 1970), would require an amendment defining as a nuisance only those establishments iu which illegal prostitution, as defined by state law or local ordinance, are held to occur.

27. Cal. Penal Code $\S 647$ (enacted 1854 and reenacted 1872) (West 1970).

28. See, e.g., Sherry, Vagrants and Vagabonds-Old Concepts in Need of Revision, 48 Caluf. L. Rev. 557 (1960) [hereinafter cited as Sherry]. One such statute in particular, CaL. Penal CODE $\$ 647(11)$ (West 1970), which defined "every common drunkard" as a vagrant, was declared unconstitutional in In re Newbern, 53 Cal. 2d 786, 350 P.2d 116, 3 Cal. Rptr. 364 (1960).

29. Ch. 560, § 2, [1961] Stat. 1672, repealing CaL. Penal CODE $\$ 647$ (codified at Cal. Penal Code $\$ 647$ (West 1970)).

30. Cal. Penal Code $\S 647$ (b) (West 1970). The definition of prostitution was added in 1965, originally reading "between persons of the same sex for money or other consideration." The words "of the same sex" were deleted in 1969. In addition, section 647 requires the imposition of 45 days in the county jail if a previous conviction for section $647(\mathrm{~b})$ is proven or admitted and a mandatory 90 day sentence if two or more prior convictions are proven or admitted. The section enables prosecutors to charge prior convictions if the defendant requests a trial while not doing so in return for a guilty plea.

31. Professor Sherry, the author of the 1961 revision, does not offer any rationale for section $647(\mathrm{~b})$, unlike the section's other subdivisions, beyond renarking that "the 
The drafters of the Model Penal Code, although removing all criminal penalties from consensual adult sexual behavior in a noncommercial context, nonetheless retained criminal penalties for acts of both prostitution and solicitation. ${ }^{32}$ The reasons advanced by the Code's drafters are (1) the prevention of venereal disease, (2) the prevention of crimes associated with prostitution, (3) the prevention of official corruption, and (4) the protection of the family and society in general from the deleterious effects of commercialized sex. ${ }^{33}$ The San Francisco Committee on Crime added (5) the protection of prostitutes, particularly minorities and juveniles, from those who would exploit thein, and (6) the protection of the general public from offensive, visible activities of prostitutes. $^{34}$ These objectives and the assumptions that underlie them will now be examined in the light of recent studies of prostitution ${ }^{36}$ in an effort to determine the degree to which they are effectively promoted by making prostitution a criminal offense.

\section{Venereal Disease}

Prostitution is often thought to be a major factor in the spread of venereal disease. ${ }^{36}$ Yet recent studies indicate that prostitution accounts

pimp, the panderer and the prostitute cannot be permitted to flaunt their services at large." Sherry, supra note 27, at 566. Nor is any rationale offered for the law, other than the proscription of conduct rather than status, in Selected 1960-61 California Legislation, 36 CALIF. ST. B.J. 801 (1961).

32. Model Penal Code $\$ 251.2$ (Prop. Off. Draft 1962) provides:

(1) Prostitution. A person is guilty of prostitution, a petty misdemeanor, if he or she:

(a) is an inmate of a house of prostitution or otherwise engages in sexual activity as a business; or

(b) loiters in or within view of any public place for the purpose of being hired to engage in sexual activity.

It is evident that in heterosexual prostitution, only the woman's conduct is criminal under this section. The customer's acts constitute a violation, punishable only by a fine. $I d$. $\S$ 251.2(5).

33. Model Penal Code $\$ 207.12$, Comment at 169-74 (Tent. Draft No. 9, 1959). Similar rationales are reportedly voiced by police. See L. TIFFANX, D. McInTYRE \& D. Rothenberg, Detection of Crime 228 (1967) [hereinafter cited as Detection of CRIME].

34. S.F. CoMmTttee on Crime, supra note 2, at 27.

35. The principal empirical sources will be the S.F. COMMITTEE ON CRIME, supra note 2; Stenn, supra note 23; Wrnick, supra note 3; The Politics of Prostrtution, supra note 4; James \& Burstin, Prostitution in Seattle, 25 WASH. Sr. B. News 5 (1971) [hereinafter cited as James \& Burstin]. 'The latter two sources are based on Dr. James' 3-year study of Seattle's prostitute population.

36. The Code's drafters cite several authorities to this effect. None is more recent than 1946. Model PeNal CODE § 207.12, Comment at 173-74 (Tent. Draft No. 9, 1959). The dates are significant, for although prostitution may have accounted for the spread of venereal disease at the turn of the century, medical advances since that time have altered the scope of the problem. Since 1945 both gonorrhea and syphillis havo been treated successfully with antibiotics when detected in time. 
for less than 10 percent of the current venereal disease incidence. ${ }^{37}$ Those age groups in which the venereal disease rate is the highest are those in which patronage of prostitutes is rather low. ${ }^{38}$ An increase in sexual activity among young people, the lack of awareness of the causes of venereal disease, and the necessity of receiving prompt treatment and informing one's partners appear to be the inajor causes of the increase in venereal disease. ${ }^{39}$ These factors suggest that increased attention toward educating the general public about venereal disease would have a more significant impact on the problem than efforts directed at prostitution. ${ }^{40}$

Various schemes providing for inedical inspection of prostitutes have proven to be ineffective both because venereal disease is difficult to detect in woinen and because a prostitute with frequent contacts may become a carrier between examinations. ${ }^{41}$ By neglecting the customer, such programs are also limited in their effectiveness. Promoting greater public awareness of venereal disease and increased efforts to find more effective methods of treatment would probably have a wider impact on the problem. In summary, current attempts to control venereal disease through the control of prostitution are effective only to the degree that prostitution is actually deterred; and even assuming a significant deterrent effect, the impact on the total incidence of venereal disease will probably be small.

\section{Associated Crimes}

Both prostitutes and their customers are sometimes the victims of robbery, assault, and even inurder. ${ }^{42}$ The environment in which street prostitution in particular occurs appears to be conducive to other kinds of criminal behavior, ${ }^{43}$ perhaps because prostitution itself is a criminal

37. Winick, supra note 8, at 64; James \& Burstin, supra note 35, at 8; see also sources cited in Polmtics of Prostrtutron, supra note 4, at 50.

38. "The age group 15-30 was responsible for $84 \%$ of the reported cases of gonorrhea in Washington (1970).... Prostitutes interviewed in Seattle report that $70 \%$ of their customers are between 30 and 60 years of age." James \& Burstin, supra note 35 , at $8 \mathrm{n} .22$.

39. Politics of Prostitution, supra note 4, at 50.

40. Id.

41. George, supra note 18, at 738-39. Quarantime of prostitutes has been used as a harassment technique. J. SkolNICK, JusTICE WITHOUT TRLAL 107-08 (1966) [hereinafter cited as Justice Without TruaL].

42. James \& Burstin, supra note 35, at 8 n.18. Sixty-four percent of the prostitutes interviewed by Jaines reported receiving injuries from customers. James' research indieates that the prostitute, not the customer, is more often the victim of an assault. See Poumtics of Prostriution, supra note 4 , at 56 . The author has been unable to find police department statistics of assaults on customers.

43. James disputes police contentions that suppression of street prostitution will lead to a significant reduction in street crime, believing that the connection between the 
offense. Both prostitutes and their customers are reluctant to report assaults and robberies to the police for this reason. ${ }^{44}$ That the service she is providing is criminal inay also blur, for the prostitute, the line between legal and illegal conduct in general. ${ }^{45}$ The same may be true for the customer, particularly if he feels that the enforceinent of prostitution laws primarily against prostitutes ${ }^{46}$ renders his behavior less culpable and his arrest less probable. Reinoving the criminal penalties froin the act of prostitution inay, therefore, both decrease associated crimes and encourage the victims of these crimes to report them to police. ${ }^{47}$ It has also been argued that allocating police resources directly to these crimes rather than to prostitution and solicitation inight reduce their incidence. ${ }^{48}$

The association of prostitution with narcotics use has also been advanced to justify retention of crininal penalties for prostitution. A distinction, however, should be made between an addiction caused by prostitution and one inerely incidental to it. An example of the former type is that of the prostitute encouraged by her pimp to become an addict so that he may insure his domination over her. ${ }^{40}$ To the extent that decriminalization of prostitution would reduce the functional necessity of the pimp in the prostitute's liveliliood, this causal association would be eliminated. ${ }^{50}$ Typical of the incidental association is the female addict who turns to prostitution because for a woman the sale of sexual service is one of the inore ready sources of quick noney for drugs rendered so expensive by their illegality. ${ }^{51}$ Undesirable as this alternative may be, it is perhaps less productive of social harm than robbery. The criminal status of prostitution does not make the addict-prostitute more amenable to treatment, though she may coine to the attention of the authorities when she is arrested for prostitution. As with venereal disease, legislation aimed directly at the treatment of drug abuse would probably have greater impact on the problem.

Finally, the association of organized crime with prostitution has been advanced as a reason for the retention of criminal penalties for prostitution. Although organized crime and "vice rings" nay have

two has been overstated. Polmics of Prostriunion, supra note 10, at 64 . The San Francisco Committee on Crime reported a substantial incidence of robbery, however. S.F. COMMTTTEe on CRIME, supra note 2, at 28-29.

44. S.F. COMMitTeE on CRIME, supra note 2, at 28-29.

45. Id. at 28.

46. See text accompanying notes 223-53 infra.

47. James \& Burstin, supra note 35, at 8, 28.

48. S.F. Committee on CRIME, supra note 2, at 29.

49. Id. at 30.

50. See text accompanying notes $62-70$ infra.

51. See Justice Without TRIAL, supra note 41, at 207. 
been associated with prostitution in the past, ${ }^{52}$ the President's Task Force on Crime $^{53}$ reported a decline in this involvennent in recent years. To some extent the decline is traceable to the replacement of the "organized" brothel by the less organized activities of streetwalkers and call girls, a consequence of laws against prostitution. There are indications that organized crime syndicates are still involved in prostitution, but that the ownership of "prostitution hotels" and massage parlors has replaced more direct connections. ${ }^{54}$ To the degree that criminal penalties for prostitution contribute to the profit to be derived from such use of these facilities, the removal of criminal penalties might discourage the intervention of organized crime. Although it is not clear what effect decriminalization of prostitution would have on its relationship with organized crime, the experience of Prohibition suggests that the opportunities for organized crime increase when the service for which there is a preexisting demand becomes criminal.

To conclude, assuming that the control of prostitution niay assist in the reduction of associated criminal behavior, it should be recognized that the control of prostitution per se inevitably involves some diversion of the resources of the criminal justice system away from other crimes. The consequences of this diversion should be weighed against the benefits that accrue from enforcement of the present prostitution laws. ${ }^{55}$

\section{Official Corruption}

Crimes that lack complaining victims, particularly those involving a significant demand for services that the law defimes as illegal, are frequent sources of official corruption. ${ }^{56}$ When prostitution received sonie degree of official toleration, police were often involved in providing protection from arrest in exchange for payoffs. ${ }^{57}$ Today, sporadic and selective enforcenent also create opportunities for the corruption of officials. Although a concerted effort at suppression of prostitution may reduce the opportumity for corruption, so long as criminal penalties remain and the demand for prostitution does not significantly decline, these possibihities will continue.

52. See note 12 supra.

53. PRESIDENT'S CoMmission ON LAW ENFORCEMENT AND tHE ADMTISTRATION of Justice: The Challenge of Crime in a Free Society 189 (1967).

54. SHEehY, HustLIng 13-14, 121-22 (1973).

55. Id. at $1-2$, noting that in 1969 only 13 percent of all murders, forcible rapes, robberies, aggravated assaults, burglaries, larcenies, and auto thefts were solved, while 50 percent of all arrests were for nonvictim offenses. The Report had initially classed prostitution as a nonvictim crime. The crimes listed above are those classified as inajor crimes in the FBI UNIFORM CRIME REPORTS.

56. Justice Without Trial, supra note 41, at 207-08.

57. S.F. COMMTTIEE ON CRIME, supra note 2, at 18. 


\section{Protecting Prostitutes}

An original motive behind the laws aimed at suppressing prostitution was the protection and redemption of prostitutes. ${ }^{58}$ The protection of women, particularly juveniles and minorities, from exploitation was a major concern of the San Francisco Committee on Crime. ${ }^{69}$ In considering this rationale there are two factors to be explored: the extent to which the law affords protection against exploitation and the degree to which, through arrest, it provides some measure of rehabilitation.

Prostitutes are the most visible of those involved in what has become a multimillion dollar enterprise. ${ }^{60}$ Among those who profit from the activities of prostitutes are the owners of bars, motels, and hotels. The prostitute's vulnerability to arrest increases her dependence on those who are willing to allow her to use their facilities. To sonne extent, then, the criminal status of prostitution creates conditions for exploitation by restricting the mode of operation of street prostitutes in particular. $^{\text {}}{ }^{1}$

The relationship between a prostitute and her pimp is more complex, although the functions performed by pimps are also partially a consequence of the criminal status of prostitution. Researchers differ regarding the frequency with which prostitutes associate with pimps and the degree of coercion which the relationship involves. ${ }^{62}$ Pimps seldom actively recruit women to become prostitutes; ${ }^{; 3}$ rather, prostitutes, particularly streetwalkers, choose to associate with a pimp for a variety of reasons. Pinps provide protection, which street prostitutes need because the environment in which they work makes them vulnerable to robbery and assault. Pimps also provide bail and obtain legal services in

58. PIVAR, supra note 9 , at 25.

59. S.F. COMMTTTEE oN CRIME, supra note 2, at 34.

60. SHEeHY, supra note 54, at 4. Sheehy estimates the "take" at between $\$ 7$ and $\$ 9$ billion annually, although the figure seems a bit high. See notes 92-94 infra and accompanying text for an estimate of the number of prostitutes and their customers.

61. Call girls, who are less vulnerable to arrest because of their lower visibility, may work out of their own apartments and thus avoid most of this kind of exploitation. If street prostitutes did not have to rent a room for each encounter to avoid arrest, owning prostitution hotels would be much less profitable.

62. WinICK, supra note 8 , at 120 , remarks that most prostitutes today do not affiliate with pimps. But the S.F. Commitree on CRIME, stupra note 2, at 34-35, found significant-numbers of street prostitutes to be involved vith pimps, who frequently maintained their control over the women through drugs and physical force, preventing them from leaving prostitution. James, on the other hand, sees the relationship as "an exaggeration of the male-female relationships in the larger society" and believes that the level of violence and abuse in prostitute-pimp relationships is comparable to that in "straight" relationships. Pourtics of Prostitution, supra note 4, at 61.

63. Poumtics of Prostrtution, supra note 4, at 45. The S.F. Commitree on CRIME, supra note 2 , at 34 , found some recruitment of young black women by pimps. Individuals informed about prostitution in Oakland have told the author that the activities of pimps are a serious problem in the minority communities in Oakland as well. 
the event a prostitute is arrested, ${ }^{64}$ while managing her affairs and taking care of her children when she is in jail. ${ }^{65}$ Removing the threat of crimmal penalties from the prostitute would to some extent lessen her dependence on a pimp. ${ }^{66}$ The other motives for affiliating with a pimp-the need for status and affection as well as the need for a business manager-arise less from the criminal status of prostitution than from the status of women in our society. ${ }^{67}$ These motives would therefore not be so greatly affected by decriminalization; however, removing some of the stigina from their occupational choice might lead to greater selfesteem and self-reliance among prostitutes. ${ }^{68}$ Although the imposition of criminal penalties on prostitution itself may not result in protecting prostitutes, the laws against pimping and procuring ${ }^{69}$ more clearly serve this purpose. Vigorous enforcement of these laws, particularly where young prostitutes are involved, would advance this goal. ${ }^{70}$

A further consideration is the extent to which the law helps or hinders the rehabilitation of prostitutes. The inquiry is a complex one, partially because prostitutes are often hostile to the very notion of rehabilitation. ${ }^{71}$ For those who luave been arrested, leaving "the life" becomes more difficult in view of the problems that persons with arrest records have in finding legitimate employment. ${ }^{22}$ The criminal status of prostitution, insofar as it may tend to encourage other forms of criminal behavior in prostitutes, may furtlier discourage a return to the "straight" world. The economic factors that lead many women to

64. WiNTCK, supra note 8, at 109; James \& Burstin, supra note 35, at 29-30, noting that many bonding agencies will not provide bond for women.

65. Most prostitutes have children, according to James. Pourrics of ProstrutTHoN, supra note 4 , at 48.

66. Id. at 60-62; S.F. CoMmTtTe on CRIME, supra note 2, at 26.

67. James \& Burstin, supra note 35, at 30. Many women feel that association with a man will bring increased status and respect, and many have not received adequate training in the management of money. James notes that many prostitutes have conservative attitudes toward sex roles. Polmics of Prostriution, supra note 4, at 60 .

68. Call girls, who are less vulnerable to arrest, apparently seldom have pimps. Stern, supra note 23, at 18; Politics of Prostrtution, supra note 4, at 62 . They are also less in need of protection because of the more genteel environment im which they work. Their background frequently reflects a higher socio-economic and educational level than that of the streetwalker, which may in part account for their greater selfreliance. STEIN, supra note 23 , at 17 .

69. Cal. Penal CODE $\S \S 266 \mathrm{~h}, 267$ (West 1975).

70. Although the San Francisco Committee on Crime found little enforcement of the law against pimping in 1971, S.F. CoMMTTree on CRIME, supra note 2, at 35-37, there appears to be increasing attention given to pimps today. Petition for Writ of Prohibition at 12, Hartway v. Municipal Court No. 467688-2 (Alameda County Super. Ct., Aug. 21, 1975).

71. Lindsay, Prostitution-Delinquency's Time Bomb, in SEX Discrimmation aND THE LAW 900 (Babcock, Freedman, Norton \& Ross ed. 1975).

72. See generally Comment, The Revolving Door: The Effect of Employment Discrimination Against Ex-Prisoners, 26 HAST. L.J. 1403 (1975). 
choose prostitution ${ }^{73}$ are not improved by the imposition of criminal penalties on prostitutes. ${ }^{74}$ To the extent that arrest does allow prostitutes to receive medical attention, counseling, and a respite from the rigors of their life, it may have positive effects. ${ }^{75}$ The reluctance of prostitutes voluntarily to seek assistance from social agencies suggests that it may be difficult to provide such services through less onerous means. ${ }^{76}$ Nonetheless, the imposition of criminal sanctions on prostitutes appears, on balance, to have increased their dependence on pimps and others who exploit them with only minimal benefit in the way of rehabilitation. ${ }^{77}$

\section{Public Offense}

Even among those who do not oppose prostitution on moral grounds, the potential for public offense in overt street activity generates support for some use of the law to control prostitution and solicitation. The San Francisco Committee on Crime recognized that these concerns were substantially based in fact. ${ }^{78}$ The criminalization of nonpublic acts of prostitution, however, has hittle effect on street solicitation-in fact that portion of the law proscribing acts of prostitution is rarely enforced. ${ }^{79}$ By prohibiting discreet forms of solicitation, the law may even tend to cause soine prostitutes and their custoiners to resort to public places. ${ }^{80}$ Thus the San Francisco Crime Committee advocated the removal of criminal penalties froin discreet prostitution. In this way prostitutes presently walking the streets would be encouraged to use less public channels, and law enforcement could concentrate its resources on the remaining street activity. ${ }^{81}$

73. See notes 104-109 infra and accompanying text.

74. See text accompanying notes 223-53 infra on selective enforcement.

75. Lindsay, supra note 71 , at 899 .

76. Id. Some have suggested treatment programs similar to those provided for drug addicts and alcoholics as an alternative to incarceration. WiNick, supra note 8 , at 289-92.

77. S.F. Committee on Crime, supra note 2, at 25-26; Polttics of ProsttruTION, supra note 4, at 60,66 .

78. S.F. COMMTTRE on CRIME, supra note 2, at 38.

79. In San Francisco, for example, 95 percent of all arrests under section 647(b) are for solicitation rather than for acts of prostitution. Record at 70, People v. Richardson, No. M48961 (S.F. Mun. Ct., Oct. 4, 1975).

80. Although there is a great deal of discreet prostitution and solicitation involving call girls, it is impossible to gain access to this branch of the profession without an "inside" contact. STrn, supra note 23, at 8 . In an interview with the author, a former call girl suggested that some solicitation currently taking place on public streets would be unnecessary if the means for private solicitation were legal and therefore more accessible to both prostitutes and clients. See also Bryan, Apprenticeships in Prostitution, in Sexual Deviance 146 (J. Gagnon \& W. Simon ed. 1963).

81. S.F. COMMTTEe ON CRMME, supra note 2, at 39. To the extent that minorities are disproportionately represented among the ranks of streetwalkers, however, such 


\section{Prostitution and Morality}

At the root of laws giving prostitution criminal status is the judgment that it is sufficiently immoral that it ought not to be given legal toleration. $^{82}$ Like other laws governing sexual behavior, laws against prostitution are an attempt by one part of society to impose its moral code on another. The extent to which the legislature can impose sanctions on private conduct in a inanner consistent with the emerging constitutional right of privacy will be discussed in a later section. ${ }^{83}$ At this poimt our focus is on the assumptions that underlie "norals legislation" and the extent to which these assumptions reflect current social realities.

One assumption behind the prostitution laws is the belief that immoral conduct must be prohibited because of its harmful social and moral effects. Beyond the problems sometimes associated with prostitution-its connection with other crimes, venereal disease, and the offensiveness of street solicitation-is the effect that commercialized sexual activity has on the social and moral environment of a commumity. Such effects are virtually impossible to identify and measure because they are largely intangible. The degree to which these effects are perceived as harmful also varies throughout the population. ${ }^{84}$ As a practical matter, the law cannot effectively prohibit all forms of conduct that some groups find immoral. The question is simply one of priorities. Does the prevention of these intangible harms justify the diversion of scarce legal resources from major crimes? ? $^{85}$ Or 1 might the law be more effectively used if restricted to that part of prostitution that has the greatest impact on the public?

A second assumption imderlying "morals legislation" is the behef that such laws validly reflect a social consensus of moral behavior that ought to be enforced. Lord Patrick Devlin, a forceful advocate of this position, has concluded that because the moral consensus is what bimds a society, individual choice im such matters cannot be tolerated without thereby threatening the bonds on which society is based. ${ }^{88}$ Even granting the validity of his syllogistic reasoning, the issue remains whether a social consensus indeed exists that legitimizes current prostitution laws.

Although prostitution was once regarded as the primary social

enforcement will fall most heavily on minority prostitutes rather than call girls, the majority of whoin are apparently white. Haft, Hustling for Rights, 1 CIV. LIB. REv. 8, 14 (1974) [hereinafter cited as Haft].

82. S.F. CoMmTTte on CRIME, supra note 2, at 27. See also Esselstyn, supra note 21 , at 125 .

83. See text accompanying notes 171-223 infra.

84. See notes 87-91 infra and accompanying text.

85. See note 55 supra and accompanying text.

86. P. Devin, The ENFORCEMENT OF MORAIS 9-25 (1965). 
evil, ${ }^{87}$ recent public opinion surveys indicate that as attitudes toward sexuality in general have changed, attitudes toward prostitution have also changed. In 1971 Assemblyman Leroy Greene of Sacramento introduced a bill to legalize prostitution and place it under some degree of state control. ${ }^{88}$ A representative sample of the state's residents were questioned by the California Poll regarding this proposal. Fifty percent responded that legalized prostitution was a "good idea" while 42 percent found it a "poor idea." 89 Asseinblyman Greene polled his constitutents, and of the 15,000 questionnaires returned, 69 percent favored his proposal. ${ }^{90}$ A Harris Survey 2 years later reported that only 46 percent of a nationwide sample regarded prostitutes as doing "more harm than good." ${ }^{11}$ Given these attitudes, it is no longer clear that laws making prostitution a criminal offense reflect a moral consensus that warrants retention in their present form.

Assuming a majority no longer favors the retention of criminal penalties for prostitution, a substantial and vocal minority probably favors retention of the present law on noral grounds. In addition, the probable harm created by the association of prostitution with venereal disease and other crimes, and the public offense created by overt solicitation, together provide a basis for soine form of criminal status if it can be shown that the law does in fact serve as a deterrent. By examining the causes of prostitution in greater detail, we can arrive at sone conclusions regarding the degree to which the problem is amenable to control through the criminal law and what kinds of law and law enforceinent would prove inost effective.

87. Public attitudes toward prostitutes and prostitution have fluctuated greatly. The propaganda battle waged by the "purity crusaders" was largely responsible for the characterization of the prostitute as a "fallen woman," an image reflected in the words of one California judge early in this century:

The fallen woman alone carries on the traffic [in prostitution]. If others prey on her frailty, it is only with her cooperation. ... The most casual observer cannot fail to see a vast difference between fallen women and the balance of humankind. They stand apart. No other body of malefactors constitute so distinctly a class as do the fallen women ..... In truth, from the standpoint of public health they are sometimes referred to as pestilential and their places of abode as pest houses.

In re Carey, 57 Cal. App. 297, 304-05 (3d Dist. 1922).

88. See note 153 and accompanying text infra. 1971).

89. The California Poll, Field Research Corporation Release No. 718 (May 28,

90. Assemblyman Leroy F. Greene Press Release, April 26; 1971 . These responses represented approximately 25 percent of questionnaires inailed.

91. The Harris Survey (Oct. 1, 1973). This compares with 88 percent who considered as harmful government officials who try to use official intelligence agencies for political advantage; 81 percent who disapproved of businessmen who give illegal campaign contributions to candidates; and 78 percent who believed that military leaders who conduct secret bombing raids and then cover up such raids do "more harm than good." 


\section{The Causes of Prostitution}

\section{The Customer}

Simply put, prostitution persists because there is both a demand for it and a sufficient number of women willing to supply this demand. It is difficult to estimate the numbers of either prostitutes or their customers. Estimates of the number of full-time prostitutes nationwide range from 100,000 to $550,000.92$ Taking the more conservative figure and assuming a weekly average of 15 contacts for each prostitute, the total would amount to $1,500,000$ customer visits each week. ${ }^{93}$ As most men have only occasional contact with prostitutes, the actual number of customers would be well in the millions. ${ }^{94}$ Although Kinsey reported a greater frequency of visits to prostitutes by lower class men and single men, ${ }^{95}$ more recent observations suggest that the typical chentele of both streetwalkers and call girls is predominantly middle-aged, middle-class married men. ${ }^{96}$ Prostitutes offer these men variety and an opportunity for sexual experiences in which only the man's needs matter. In the context of prostitution he can imdulge these needs in ways that he cannot or will not with his regular partners. ${ }^{97}$ The skillful prostitute creates a fantasy world in which repressed desires can be acted out in safety, and may thus function as a paraprofessional sex therapist. ${ }^{98}$ Moreover, within the context of prostitution, extramarital sex poses few of the dangers to a man's marriage that an "affair" would entail; essentially it is sex without risk. ${ }^{99}$ In addition, prostitutes provide sexual access for a smaller number of men who are unable, because of physical disabilities, unattractiveness, or personality problems, to find nonprofessional partners. ${ }^{100}$

92. WinrcK, supra note 8 , at 4-5.

93. Winick uses an average of 18 contacts per week. Id. This is conservative. STEn, supra note 22 , at 24 , states that full-time call girls see from 20 to 30 clients a week.

94. The Kinsey Report indicated that 69 percent of the adult inale population have visited a prostitute at least once, though only $15-20$ percent go more than a few times a year. A. Kinsey, W. Pomeroy \& C. Martin, Sexual Behavior in the Human Male 597 (1948) [hereinafter cited as KINSEY]. The number of full-time prostitutes active in Oakland has been conservatively estimated at 500. This would indicate an average of roughly 10,000 customer visits per week in that city. Petition for Writ of Prohibition at 59, Hartway v. Municipal Court No. 467685-2 (Alameda County Super. Ct., Aug. 21, 1975).

95. KINSEX, supra note 94, at 598-99.

96. James \& Burstin, supra note 35, at 28; Polmics of Prostrtution, supra note 4, at 52; STEIN, supra note 23, at 95-96; WINICK, supra note 8, at 195.

97. STEn, supra note 23, at 101-05; WINICK, supra note 8, at 193, 196, 207, noting at 207 that oral copulation is more frequently sought than regular intercourse.

98. Stein, supra note 23, at 2; Polmtics of Prostrtution, supra note 4, at 52.

99. KINSEX, supra note 94, at 606-07; Esselstyu, supra note 21, at 117.

100. PoLITICs of Prostirution, supra note 4, at 53. 
Regardless of the desirability of the custoiners' underlying motives from a social or moral viewpoint, they point to some conclusions. First, given men's reasons for visiting prostitutes, the deinand for prostitutes' services seeins likely to continue, although increased openness regarding sexuality among men and women generally may contribute to a decline in this demand. ${ }^{101}$ Second, because patronage of prostitutes occurs among influential segments of society, ${ }^{102}$ enforcement of the law against customers may have significant deterrent effects, particularly if it is accompanied by publicity. The application of the law equally to customers may engender some resistance, however, and may lead to increased pressure for reform. ${ }^{103}$ So long as criminal penalties are applied primarily against prostitutes, lowever, enforcement can be expected to have little effect on the demand for prostitution.

\section{The Prostitute}

Women become prostitutes for a variety of reasons. Rather than being coerced by others, most prostitutes today appear to lave exercised some degree of choice in entering "the life."104 The reasons for these choices are social, economic, and psychological. Viewed from a societal perspective, many of the women who enter "the life" have already experienced some problems in conforming to society's norms, such as difficulties in the hoine, in school, or on the job; or im overcoming persistent social handicaps, such as drug dependence, einployment discrimination, culturally ingrained restrictions on career choices available to women generally, ${ }^{105}$ or desertion by a man who might have supported them. ${ }^{106}$ Women who thus find themselves inadequately prepared to

101. WnICK, supra note 8 , at 284-85.

102. "Prostitutes in Seattle report their customers' occupations as follows: $35 \%$ businessmen, $10.6 \%$ salesmen, $11.4 \%$ lawyers-accountants, $13.8 \%$ Boeing employees, 3.3\% Merchant Marine, 4.1\% Armed Services." James \& Burstin, supra note 35, at 28 n.30.

103. For example, when it was ordered that the practice of quarantining those arrested for violations of section 647 (b) be equally applied to customers, requiring several men to spend 5 days in jail awaiting the results of their venereal disease tests, the practice was immediately discontinued. The order was issued in Riemer v. Jensen, No. 455371 (Alameda County Super. Ct., Feb. 26, 1975). Interview with Spurgeon Avakian, Superior Court Judge, in Oakland, Jan. 29, 1976.

104. Politics of Prostrtution, supra note 4, at 44-45. The Committee on Homosexual Offenses and Prostitution in Great Britain stated a similar conclusion:

Our impression is that the great majority of prostitutes are women whose psychological make-up is such that they choose this life because they find in it a style of living which is to them easier, freer and more profitable than would be provided by any other occupation.

Committee on Homosexual OfFenses and Prostitution, Report, CMD No. 247, at 13 (1957) [hereinafter cited as Wolfenden Report].

105. See generally Comment, Teaching Woman her Place: The Role of Public Education in the Development of Sex Roles, 24 HAST. L.J. 1191 (1973).

106. Model Penai Code $\$ 207.12$, Comment at 170, (Tent. Draft No. 9, 1959). 
meet the necessity of supporting themselves may choose prostitution as their means of support. Many also wish to avoid reliance on a welfare system they often perceive as a degrading and dehumanizing experience. ${ }^{107}$

As an economic matter, prostitution often proves more rewarding than low-paying legitimate employment or welfare, particularly for those with poor education and few other marketable skills. Call girls, who frequently come from higher socio-economic and educational backgrounds, also find that prostitution provides more money for less work than such jobs as teacher or secretary. ${ }^{108}$

From a psychological viewpoimt, it is plausible to assert that in a society in which women are to some extent regarded as sex objects and are often subtly encouraged from an early age to play upon their attractiveness to gain popularity and favors from men, a decision to resort to more overt exploitation of one's sexuality may follow when more traditional avenues of adjustment prove unsatisfactory. ${ }^{109}$ Particularly for a woman who has already been promiscuous, turning to prostitution may amount to capitalizing on what society has already defined as a valuable asset. To some this choice may appear to be a degradation of this asset; yet it may also be viewed as a choice by the prostitute to exercise control over her own sexuality, giving her greater economic and psychological independence than may otherwise be available.

Again, regardless of the moral evaluation we may wish to place on a prostitute's choice of lifestyle, two related conclusions may be drawn. First, as we saw above, many women become prostitutes voluntarily; therefore, legislation aimed at expanding the occupational choices open to women and providing them with the means to accept these choices may help to make prostitution a less desirable alternative. Second, prostitution laws appear to have little deterrent effect on prostitutes themselves. These laws are enforced primarily against prostitutes, not

107. James \& Burstin, supra note 35 , at 29.

108. STEn, supra note 23, at 24 , reports that full-time call girls in New York make from $\$ 50,000$ to $\$ 100,000$ per year.

109. As Jennifer James observed in her study of Seattle's prostitute population:

The psychological approach has traditionally rested on the impact of deprivation during childhood. We believe that another socio-psychological factor is operant: society's definitiou of the female as a sexual commodity. This basic image of female sexuality combined with the 'double standard,' places many women in the personality structure of the prostitute long before inoney changes hands. Society considers the sex experiences of a man as attributes if not milestones in his developinent. Similar experiences in the life of a woman represent loss of virtue and degradation. Women though, in all classes of this society, are taught to 'hustle' at an early age in order to sell themselves. It becomes, for some, inerely a question of degree; that is, to sell oneself for economic security to one man or to many men.

James \& Burstin, supra note 35, at 29. 
customers. $^{110}$ Those prostitutes who are most frequently arrested-the street prostitutes-have the least to lose and the fewest alternatives available. ${ }^{111}$ Apparently regarding arrest, fines, and even a short jail sentence as hazards of the trade, they are quickly back on the streets. ${ }^{112}$ Laws against prostitution, at least as presently enforced, therefore have minimal impact on women's choices to enter and remain involved in prostitution.

Orce it is understood that the demand and the supply that prostitution meets are both outgrowths of complex social, economic, and psychological factors, the focus then shifts to whether these factors are themselves within the reach of the criminal law. ${ }^{113}$ More vigorous law enforcement and stricter penalties might lessen the desirability of prostitution as an occupation, but this effort would require significantly greater public expenditures for police, prosecutors, courts, and jails. To complete the evaluation of existing legislation, we must measure the benefits, if any, to be gamed by continued treatment of prostitution as criminal against the costs of enforcing the law.

\section{The Realities of Enforcement}

The criminal code of any jurisdiction tends to make a crime of everything that people are against, without regard to enforceability, changing social concepts, etc. . . . The result is that the criminal code becomes society's trash bin. The police have to rummage around in this material and are expected to prevent everything that is unlawful. They cannot do so because many of the things that are prohibited are sinply beyond enforcement, both bectuse of human inability to

110. See notes 224-25 infra indicating that over 90 percent of those arrested for violations of Penal Code section 647(b) in three northern California cities are women.

111. Bilek, supra note 2 , at 88 , comments on the general ineffectiveness of criminal sanctions on those who have "little to lose by violating the law." Skolnick also remarks on the limited effect of the threat of criminal sanctions on "deviants," many of whom simply modify their behavior only enough to avoid arrest. Coercion to Virtue, supra note 3, at 623-26.

112. S.F. CoMmitTeE on CRIME, supra note 2, at 21.

113. Finding these factors to be largely beyond the reach of the criminal law, the Committee on Homosexual Offenses and Prostitution in Great Britain recommended against the imposition of criminal penalties for acts of prostitution:

Prostitution is a social fact deplorable in the eyes of inoralists, sociologists, and, we believe, the great majority of ordimary people. But it has persisted in many civilizations throughout many centuries, and the failure of attempts to stamp it out by repressive legislation shows that it cannot be eradicated through the agency of the criminal law. It remains true that without a demand for her services the prostitute could not exist, and that there are enough men who avail themselves of prostitutes to keep the trade alive. It also remains true that there are those wolnen who, even when there is no economic need to do so, choose this form of livelihood. For so long as these propositions continue to be true there will be prostitution, and no amount of legislation directed toward its abolition will abolish it.

Wolfenden Report, supra note 104, at 132. 
enforce the law and because ... society legislates one way and acts another way.

-FBI Spokesman ${ }^{114}$

\section{The Pattern of Enforcement}

In practice, the law against acts of prostitution is rarely enforced; in San Francisco, for example, 95 percent of all arrests under section 647(b) are for solicitation rather than for acts of prostitution. ${ }^{115}$ Because prostitution and solicitation are misdemeanors, to make an arrest a police officer must have probable cause to believe that the misdemeanor was actually committed in his presence. ${ }^{110}$ The practical difficulties attending this legal requirement in the prostitution context account for the one-sided arrest distribution under section 647(b).

Although the acts theinselves generally take place in private, solicitations taking place in public are often observed by police engaged in surveillance operations. When a police officer believes a solicitation lias taken place, he follows the pair to the hotel or motel rooin. He may then stand outside the door to gather further evidence, open the door with a pass key obtamed from a cooperative desk clerk, or break down the door. ${ }^{117}$ Once arrested, the pair are separated for interrogation. Even when the parties' actions or state of undress indicate that sexual acts have taken place, however, statutory limitations on the use of uncorroborated accomplice testimony make prosecution for the act itself difficult. ${ }^{118}$ In practice, then, police attempt to determine who solicited whoin and arrest the probable solicitor, using the testimony of the other party as evidence. ${ }^{110}$

Alternatively, the police may pose as customers and invite solicitations. Decoy arrests are less frequent for an act of prostitution, lowever, since an arrest of this type requires the police officer actually to take

114. President's Commission on Law Enforcement and admmistration ó Justice, TASR ForCe RePort: The CourTs 107 (Mar. 13, 1967), quoted in Coercion to Virtue, supra note 3, at 628.

115. Record at 70, People v. Richardson, No. M48961 (S.F. Mun. Ct., Oct. 4, 1975).

116. Cal. Penal Code $\& 836$ (West 1970).

117. Justice Wrthout Trus, supra note 41, at 183-85. Skolnick's study was largely based on law enforceinent in "Westville," apparently Oakland, California. Id. at 246-51.

118. Cal. Penal Code $\$ 1111$ (West 1970). As both parties are liable to be convicted, one cannot testify against the other without immunity.

119. Testimony by vice squad officer West in People v. Richardson, No. M48961 (S.F. Mun. Ct., Oct. 4, 1975), indicated that it was the policy of the San Francisco Vice Detail not to arrest the customer even when lie admits to engaging in acts of prostitution, Record at 148; the standard practice is to arrest the woman and obtain testimony from the customer that she solicited him. Record at 143. See text accompanying notes 223-53 infra on selective enforceinent. 
part in the act itself. ${ }^{120}$ Although arrests for solicitation made by the decoy method more often result in convictions because the officer is a more reliable witness than the customer, ${ }^{121}$ the tactics of experienced streetwalkers to avoid arrest limit the utility of this method. ${ }^{122}$ Given the difficulty of making arrests by either the decoy or surveillance methods, the police occasionally resort to "street sweeping" operations sometimes termed harassment arrests. ${ }^{123}$ These arrests are usually for obstructing the sidewalk ${ }^{124}$ rather than for solicitation, and they are frequently imdertaken for public relations purposes. ${ }^{128}$

\section{The Costs of Enforcement}

The San Francisco Committee on Crime concluded that it cost the city in 1967 more than $\$ 370,000$ for the 2,116 persons arrested that year for prostitution. ${ }^{126}$ But dollars and cents are not the only costs deserving of justification. The Crime Committee's conclusions further indicate that the costs of enforcenent include not only direct budgetary outlays but also hidden institutional costs. First to be considered is the cost in terms of police inorale. In the course of his investigation into the relation between law and law enforcement, one sociologist has commented that the more the law makes certain activities crininal, the

120. See Williams v. Superior Court, 30 Cal. App. 3d 8, 106 Cal. Rptr. 89 (1st Dist. 1973). Police participation in prostitution does not usually raise legal problems of entrapment, but rather of "encouragement." Entrapment requires that the initial criminal intent originate with the officer, not the defendant. People v. Benford, $53 \mathrm{Cal}$. 2d 1, 345 P.2d 928 (1959). Evidence of prior criminal behavior on the defendant's part may be imtroduced to prove intent, People v. Foster, 36 Cal. App. 3d 594, $111 \mathrm{Cal}$. Rptr. 66 (1st Dist. 1973), making it difficult for any woman previously arrested under section 647(b) to argue entrapment successfully. Encouragement, as contrasted with entrapment, involves police officers who (a) pose as victims, (b) intend to encourage suspects to commit crimes, (c) communicate this encouragenient to the suspect, and (d) thereby influence the commission of a crime. Detection of CRIME, supra note 33, at 210. For a discussion of the problems associated with this technique, see id. at 273-82.

121. Sergeant Dower of the San Francisco Police Department Bureau of Special Services Prostitution Detail testified that customers frequently do not appear in court or are unable to give testimony sufficient to convict, given the subtleties of the transaction. Record at 203, People v. Richardson, No. M48961 (S.F. Mun. Ct., Oct. 4, 1975). See also S.F. COMMTTTEe ON CRIME, supra note 2, at 22.

122. For example, the woman frequently tries to maneuver the customer into making an offer of money, while being vague and euphemistic herself. S.F. CoMMrrTEE on Crime, supra note 2, at 22; Record at 182-205, People v. Richardson, No. M48961 (S.F. Mun. Ct., Oct. 4, 1975); Justice WrThout Trual, supra note 41, at 102-03.

123. Detection of Crime, supra note 33, at 229.

124. Cal. Penal Code \$ 647(c) (West 1970).

125. S.F. Committee on Crime, supra note 2, at 23. The Committee also noted that prostitution arrests tended to fluctuate greatly, apparently in response to political pressure. Id. at 10.

126. S.F. Commttee on Crime, supra note 2, at 20. James \& Burstin estimated that it cost the city of Seattle in excess of $\$ 1$ million to attempt unsuccessfully to control prostitution in 1973. James \& Burstin, supra note 35 , at 29. 
more the environment in which the police must work is "criminalized." 127 The initial effect is to make the policeman's environment more dangerous, as there are now more potential criminals with whom he must deal. Confrontations with innocent citizens may imcrease. When substantial numbers of the community do not agree that the conduct $\mathrm{m}$ question should be criminal, the authority of the policeman is undermined, increasing his sense of alienation from the community lie is supposed to serve. ${ }^{128}$ Simce much street solicitation takes place in areas of high nonwhite population, prostitution laws may increase community tensions, particularly when only the prostitute and not her customer is arrested. ${ }^{128}$

A further potential consequence of criminalizing the environment is the criminal involvement of the police theniselves. The enforcement of "morals offenses," crimes that by definition do not have victims who bring complaints to the police, places the police in a role different fron that ordmarily required of them in the enforcement of other laws. Absent complaints, the police must seek out and report infractions themselves. This more active role apparently leads police to resort to a more intrusive surveillance of potential offenders, increased reliance on decoys and informers, and inore questionable searches and seizures. ${ }^{130}$ These tactics in turn bring the police into greater conflict with prosecuting attorneys and judges, who, because they are more reinoved from the street environment and more sensitive to community dissatisfaction with these laws, nray not prosecute and sentence offenders to the full extent of the law. ${ }^{131}$ They are also inclined to enforce procedural standards on the police. Prosecutorial and judicial discretion, as well as judicial limitations on police conduct, may be niterpreted by the police as criticisms of their professional abilities. ${ }^{132}$ Law enforcement officials' sense of frustration may increase, resulting in hostility between law enforcement and the judicial system. ${ }^{133}$ Moreover, the sporadic en-

127. JUSTCE WrTHOUT TRIAL, supra note 41 , at 227.

128. Coercion to Virtue, supra note 2, at 636-37.

129. Packer, The Limirs of the Criminal Sanction 328-29 (1968). The San Francisco Committee on Crime found some sentiment in minority communities that enforcement of prostitution laws was discriminatory. S.F. COMMTTTEE on CRIME, supra note 2 , at 37 .

130. Coercion to Virtue, supra note 3, at 629-32; cf. Kadish, supra note 2, at 162.

131. Responses to questionnaires sent by Assemblyman Greene to various officials mdicated that although a majority of judges favored legalization of prostitution and believed that society did not benefit from either present laws or the punishment given to prostitutes, a majority of police officials believed the opposite. Thirty-eight police chiefs believed that punishment of prostitutes benefits society while 36 did not. Press Release from Assemblyman Leroy F. Greene, June 25, 1971.

132. Justice WITHOUT TRIAL, supra note 41 , at 228.

133. Id. at 229. 
forcement, the frustration, and the uncertainty about the wisdom of "morals offenses" may lead to more overt police criminality, such as an mcreased willingness to take bribes. As a result, the whole enterprise of law enforcement is corrupted and undermined. ${ }^{184}$

The processing and prosecution of prostitution cases places strains on the judicial system as well. Once arrested, a prostitute arranges bail and returns to the streets within a day. Crowded municipal court dockets and repeated requests for continuances postpone final disposition of her case. Crowded court calendars also lead to extensive use of plea bargains, resulting in light sentences. ${ }^{135}$ By repeatedly requesting continuances, a prostitute's attorney may get her case dismissed for lack of witness testimony or may secure a better plea bargaim. ${ }^{130}$ Increasingly, prostitutes are demanding jury trials. Prostitution cases represented 30-35 percent of all jury trial requests in San Francisco Municipal Courts in 1971. ${ }^{137}$ As constitutional challenges increase, and municipal court decisions are appealed, prosecutions beconie lengthier and more costly to the state. Increasing the penalties for prostitntion as an increased deterrent will result in more deinands for jury trials, further adding to the expense, and increased jail sentences will require further expenditures. ${ }^{138}$ According to a poll by Assemblyinan Greene, the majority of judges responding did not beheve that society benefits either froin present prostitution laws or from the punishment presently meted out to those who violate thein, and a majority therefore favored the legalization of prostitntion. ${ }^{189}$

Finally, we must consider the costs that enforcement exact from those who are arrested. In addition to the obvious penalties-fines or incarceration-arrest makes it difficult for a prostitnte to return to the noncriminal world and thus may be considered a factor inhibiting her rehabilitation. Arrest and the need for legal services increase a prostitute's dependence on her pimps, ${ }^{140}$ further inhibiting her from leaving "the life." Incarceration with inore experienced criminals may lead to increased criminal behavior among prostitutes, as it does among other inmates, upon their release. ${ }^{141}$ In view of the lack of rehabilitative services within our jails, incarceration will continue to produce negligible benefits to both prostitutes and society as a whole.

134. Coercion to Virtue, supra note 3 , at 631.

135. S.F. COMMTTEE ON CRIME, supra note 2, at 25.

136. Id. at 24.

137. Id.

138. Id. at 25.

139. Press Release from Assemblyman Leroy F. Greene, June 25, 1971. Sixtyseven judges approved of the idea while 57 did not.

140. S.F. Committee on CRIME, supra note 2, at 35; Polmits of Prostitution, supra note 4, at 60-62.

141. Haft, supra note 81 , at 15 . 
Clearly, the law cannot prevent all activities that even a majority deems harmful. Given the limited impact that enforcement of current prostitution laws has on this activity and the costs of the present enforcement of those laws, the diversion of limited law enforcement and judicial resources from more serious forms of crime seems questionable. One emment criminal law scholar has aptly characterized the problem:

Only the judgment that the use of the criminal law for verbal vindication of our morals is more important than its use to protect life and property can support the preservation of these laws as they are..$^{142}$

The Comment now turns to the law as it should be.

\section{E. Some Proposals for Reform}

From the foregoing discussion of the rationales and himitations of California's current law against prostitution, we may draw several guidelines for reform. First, because some ainount of prostitution is likely to continue for the foreseeable future, legislative reform should be aimed not at its abolition, but at minimizing the undesirable aspects of prostitution, particularly overt public solicitation. Second, if redirection of prostitution away from public places is to be at all successful, some provision for discreet prostitution and solicitation should appear in the legislation, providing both those interested in prostitution and law enforcement officials with reasonably clear guidelines delineating what conduct is legal. Third, the coercive aspects of prostitution, particularly the activities of pimps, often do not constitute "victimless" activity. Continued enforcement of laws against pimping therefore appears warranted, and legislative modifications of section 647(b) should also be aimed at lessening the leverage that pimps presently enjoy over prostitutes. Fourth, in view of differences of opinion regarding prostitution, some provision for local options with respect to regulation seems indicated, although local option to prohibit prostitution presents further problems. Fifth, if prostitution activity is to be substantially reduced, some alternatives should be provided for those presently in "the life" who wish to leave it, and attention should be directed at increasing the availability and desirability of other alternatives for those who might otherwise become prostitutes.

These guidelines suggest two kinds of legislation: first, reform of the existing law to perımit prostitution and solicitation that take place out of the public view; and second, some forn of counseling and other services for those seeking an alternative to prostitution, coupled with increased efforts at broadening employment opportunities for women, particularly those of minority background.

142. Kadish, supra note 2, at 162 . 


\section{An Analysis of Current Legislative Efforts at Reform}

Two bills that have been introduced in the 1976 session of the California legislature to modify Penal Code section 647(b) will serve as a starting poimt for a discussion of possible reforms in the existing law against prostitution. Senate bill 1389, introduced by Senator Arlen Gregorio, ${ }^{143}$ would revise section $647(\mathrm{~b})$ as follows:

Every person who commits any of the following acts is guilty of disorderly conduct, a misdemeanor:

(b) (1) Except as provided in paragraph (3), who solicits or who engages in an act of prostitution.

(2) As used in this subdivision, prostitution includes any lewd act between persons for inoney or other consideration.

(3) An act of prostitution shall not violate this subdivision so long as neither of the persons engaging in the act knowingly and intentionally injures or threatens to injure the person or property of the other, nor so long as the commission of such act of prostitution causes no injury to the person or property of nonparticipating third parties to such an act.

(4) Nothing in paragraph (3) sliall be construed to autlorize any solicitation by any person in any public place or in any place open to the public or exposed to the public view, nor any solicitation in any other place by any person other than one proposing personally to engage in an act of prostitution.

(5) Any city, county or city and county may, by ordinance, prohibit or further restrict or regulate acts of prostitution and solicitation thereof, including, but not limited to, zoning of areas where acts of prostitution nay occur, reasonably regulating the health aspects of the business of prostitution, and concerning the solicitation of or engaging in acts of prostitution. Any such ordinance shall apply in addition to, and shall be inore limiting with respect to such conduct, than the provisions of state law. Such ordinance shall specify whether or not the violation thereof is a crime. Such crime, if any, shall be a misdemeanor. Failure to comply with such ordinance shall not constitute a violation of state law. ${ }^{144}$

A different approach appears in Assembly bill 3993, introduced by Assemblyman Ken Meade, ${ }^{145}$ which would amend section $647(\mathrm{~b})$ to define as guilty of disorderly conduct any person

(b) Who, on the public streets or sidewalks, solicits or who engages in any act of prostitution. Prostitution includes any sexual

143. Democrat, 10th District (San Mateo and Santa Clara Counties).

144. SB 1389, introduced Jan. 8, 1976, amended Mar. 9, 1976. In addition, the bill would delete the mandatory 45-day sentence for a seeond conviction and 90-day mandatory sentence for a third conviction under Penal Code section 647(b).

145. Democrat, 12th District (Alameda County). 
act between persons for money or other consideration. Except as provided in this subdivision, no city, county or city and county may by ordinance, or otherwise, prohibit prostitution places or acts of prostitution. However, such local governments may regulate prostitution places and prostitution by local zoning ordinances so as to insure the public peace. Furthermore, local governments may require the licensing of prostitution places and of persons who receive money or other consideration in order to regulate the public health and safety. ${ }^{146}$

Although the two bills are similar, there are important differences between them. Both clearly prohibit some forms of public solicitation, but the Meade bill prohibits only solicitation on public streets or sidewalks, apparently permitting such activity in public parks and buildings, as well as on private property such as bars or hotel lobbies. As a measure aimed at the more offensive forms of solicitation, it might therefore be somewhat undermclusive. The Gregorio bill, on the other hand, clearly prohibits solicitation in places "open to the public." Courts construing the same phrase in sections 647 (a) and 647(f) ${ }^{147}$ have leld that individual rooms in a massage parlor are "open to the public,"148 as is any business establishment serving the general public. ${ }^{149}$ A similar construction of the Gregorio bill would preclude the establishment of louses of prostitution, particularly those in which the actual solicitation is by the proprietor, and not the prostitute herself. The Gregorio bill is also unclear as to whether forms of discreet solicitation, such as advertisements in sexually oriented newspapers, would be permissible. As a means of providing legal alternatives to open street solicitation, then, the bill may be overinclusive.

The Meade bill apparently would decriminalize acts of prostitution that do not take place in public. ${ }^{150}$ The Gregorio bill, on the other hand, permits such acts only when they do not imvolve injury to persons or property, attempting to distinguish between "victimless" prostitution and prostitution where mjury to others occurs. The purpose of this distinction is not apparent, nor is it clear what kind of injury, particularly to third parties, would render the conduct criminal. As imjury is an element of the offense, the burden is on the prosecution to produce evidence of such injury. Presumably, in the case of participants this

146. AB 3993, introduced Mar. 18, 1976.

147. Penal Code section 647(a) prohibits soliciting and engaging in lewd conduct "in any public place or in any place open to the public or exposed to public view." Section 647(f) prohibits intoxication "in any public place." CaL. Penal Code $§ 647$ (West 1970).

148. In re Steinke, 2 Cal. App. 3d 569, 82 Cal. Rptr. 789 (1st Dist. 1969).

149. People v. Blatt, 23 Cal. App. 3d 148, 99 Cal. Rptr. 855 (2d Dist. 1972).

150. See Legislative Counsel's Digest accoinpanying AB 3993. 
evidence would also sustain arrest and conviction for larceny, robbery, assault, or some other offense. The bill's virtue may therefore lie in facilitating the reporting of such imcidents by removing the threat of prosecution for prostitution from the victim. The bill apparently would also preclude the use of undercover decoys except in cases where there is evidence of injury or solicitation in public places. The same results, however, could be accomplished simply by removing all criminal penalties from acts of prostitution and solicitation that take place in private. If the intent of the bill is to protect the less tangible property interests of third parties, perhaps this objective could also be accomplished more directly. Neither bill, in the last analysis, is entirely satisfactory.

\section{An Alternative Proposal}

\section{a. Minimizing Public Solicitation}

Although both bills represent laudable efforts to direct enforcement only at forms of prostitution that actually create public harm, neither appears to be entirely satisfactory in minimizing public solicitation while clearly defining legal and illegal conduct. Further, neither substantially lessens the influence of pinps, which derives from the threat of arrest. These goals might more adequately be met, for example, by amending section $647(\mathrm{~b})$ to define as guilty of disorderly conduct any person

(1) Who solicits or engages in an aot of prostitution on any public street or sidewalk, or in any public park or other place exposed to the public view, or in any building or part of a building open to the public without the permission of the proprietor of sucl establishment, unless such acts are permitted by local ordinance pursuant . to paragraph 3.151

(2) As used in this subdivision, prostitution includes any sexual act between persons for money or other consideration.

Thus amended, the law would prohibit open public solicitation, but would permit solicitation in establishments such as massage parlors, bars, or places of prostitution with the consent of the proprietor. It would also permit discreet forms of advertising, such as in newspapers or special directories, so long as the solicited acts were to take place in a private home or apartment or in an establishment where the proprietor had agreed to their commission. By permitting some prostitution, it will lessen the dependence on pinps to the extent that this dependence derives from the threat of arrest.

Botli the Meade and the Gregorio bills permit localities further to regulate prostitution and solicitation, but the Meade bill, unlike the

151. See text following note 163 infra. 
Gregorio bill, would not permit local governments to prohibit these activities. Although the latter bill has the virtue of requiring local governments to act affirmatively to prohibit such acts, presumably with ample opportunity for the expression of competing views, local option to prohibit prostitution entirely may not be desirable. Pressure for decriminalization is likely to be greatest in those cities in which the prosecution of prostitutes has required substantial allocation of law enforcement and judicial resources, and least in those areas that presently have fewer problems with prostitution. At present much prostitution activity takes place in neighborhoods with a high concentration of minorities, although studies show that the majority of the clients of prostitutes are white, middle-class men who presumably do not live in these neighborhoods. ${ }^{152}$ If suburban areas are permitted to exclude prostitution entirely, the prostitution problein in minority comınunities will be exacerbated. Prohibition of prostitution by the constituents of the larger cities is unlikely, because of political and economic factors. Thus local option to prohibit prostitution will result in the anomaly that the city dwellers will bear the entire burden of prostitution activity, while the suburbanites generate most of the demand. Permitting further regulation, though not prohibition, at the local level might more adequately balance the interests of all commumities involved.

\section{b. Regulation Through Licensing}

The Meade bill exphicitly, and the Gregorio bill imphicitly, would permit local hicensing of prostitutes and houses of prostitution. ${ }^{163}$ Several problems arise in connection with government licensing, at any level, of prostitution. One reason frequently urged in support of $\mathrm{h}$ censed prostitution is the control of venereal disease. Although any proprietor of a public, cominercial establishment is subject to regulation for health purposes, the limitations inherent in attempting to control the incidence of venereal disease produced by prostitution inust be borne in mind. ${ }^{154}$ Merely requiring prostitutes to submit to regular examination is of limited efficacy. ${ }^{185}$ Inspection of clients prior to contact, already practiced informally by many prostitutes, ${ }^{158}$ would appear more effective, if coupled with regular examinations of prostitutes. In determin-

152. See notes 102 \& 103 supra and accompanying text.

153. Asseinblyinan Leroy F. Greene, Democrat, Third District, Sacramento, introduced a bill in 1971 that would have repealed Penal Code section 647(b) and amended the Health and Safety Code to provide for licensing of prostitutes and places of prostitution by the State Director of Public Health. AB 2213, 1971 regular session, introduced April 4, 1971.

154. See notes $32-41$ supra and accompanying text.

155. See note 41 supra.

156. WINICK, supra note 8, at 63-64. STEIN, supra note 23, at 21. 
ing the degree of regulation a locality wishes to impose, the costs of involuntary examinations should be weighed against the benefits to be gained by greater education of the public in general and perhaps some expansion of community venereal disease clinics.

Although other licensing objectives-for example, minimizing the role of pimps, preventing minors from becoming prostitutes, or raising tax revenue ${ }^{157}$-may not share the practical limitations inherent in health regulations, the very involvement of government in the licensing of prostitution itself raises problems that transcend admimistrative concerns. If society is to draw a distinction between "tolerating" and "condoning" conduct it regards as undesirable, then the hicensing of prostitution would give the appearance of lending governmental approval to such activity. ${ }^{158}$ Some feminists liave also opposed the licensing of prostitutes because it implies public affirmation that sexual access is a nuale prerogative. ${ }^{160}$

Government licensing of houses of prostitution has proven ineffective in most European countries. ${ }^{180}$ Many prostitutes apparently do not like the lack of freedom and the control over their activities that licensed houses connote. ${ }^{161}$ Further, the imvolvement of government in the issuing of licenses, particularly if they were limited in number, might not remove the problems of payoffs and corruption that presently exist. Others have suggested that the issuance of a license to prostitutes may stigmatize them in much the same way as an arrest record-adversely affecting far nore prostitutes in inhibiting their transition to other forms of employment. ${ }^{162}$ On the other hand, the regulation of service occupations is widespread; a consequence of commercialization of any service may be the acceptance of the power of government to regulate in the interests of health and public welfare. If one is to accept this consequence, then it would seein preferable to have an administrative agency license prostitutes rather than houses of prostitution, revoking licenses of those who do not conform to health, zoning, and advertising regula-

157. See note 163 infra.

158. S.F. COMMTTIEe on CRMME, supra note 2, at 43.

159. See S. Brownmiller, Agatnst Our Will: Men, Women and Rape (1975). Noting the connection between rape and prostitution as based on similar views of women as objects, Brownmiller states:

[M]y horror at the idea of legalized prostitution is not that it does not function as a rape deterrent, but that it institutionalizes the concept that it is a man's monetary right, if not his divine right, to gain access to the female body and that sex is a female service that should not be denied the civilized inale. Perpetuation of the concept that the "powerful male impulse" must be satisfied with immediacy by a cooperative class of women, set apart and licensed for Id. at 392 . this purpose, is part and parcel of the mass psychology of rape.

160. Haft, supra note 81, at 22.

161. Polmics of Prostitumion, supra note 4, at 62.

162. Haft, supra note 81, at 22. 
tions. ${ }^{163}$ In short, it may well be preferable to leave the business of prostitution to a regulated "free enterprise" system, and not to involve government, be it state or local, in any extensive way in controlling private sexual behavior between consenting adults. Regulation, but not prohibition, at the local level as befits community needs would seen preferable to state regulation. Embodying these considerations, an amendment to 647 (b) dealing with local options might read as follows:

(3) Except as provided in this subdivision, no city, county, or city and county may by ordinance, or otherwise, prohibit prostitution or solicitation for prostitution. However, such local governments may by ordinance or otherwise, permit, regulate, or further restrict acts of prostitution and solicitation thereof, imcluding but not limited to, zoning of areas where prostitution or solicitation for prostitution nay occur, and reasonably regulating the health aspects of the business of prostitution.

(4) Such local governments may further require that a designated local administrative agency license persons who engage in prostitution. Any local ordinance regulating prostitution or solicitation shall therefore specify whether or not the violation thereof is a crime. Such crime, if any, shall be a misdemeanor. Failure to comply with such ordinance shall not constitute a violation of state law.

Thus amended, the law would give maximum flexibility to local communities to regulate, but not prohibit altogether, both prostitution and solicitation.

\section{c. Elimination of Mandatory Sentencing for Repeating Offenders}

One further point deserves mention. The Gregorio bill would delete the mandatory sentence for repeating offenders of section 647(b). This approach is desirable for three reasons. First, inasmuch as any modification of the law will probably be in the direction of greater liberalization, those who have been arrested under the previous law should not be further penalized in the event of a violation of the new law. Second, the mandatory sentences have not been uniformly apphed. As the San Francisco Crime Committee poimted out, to do so would require substantial outlays for court costs that the legislature did

163. James suggests:

Taxation, hygiene and age requirements can be approached in a number of ways. The least abusive to the individual woman would be a small business license with a health card requirement. Prostitutes would obtain a license much as a masseuse does; her place of business would liave to conform with zoning requirements; she would be required to report her income, be of age, and keep her health card current. Violations would mean revoking her license and would be handled by a non-police administrative agency. Advertisements would be limited to discreet classified ads. Houses of prostitution would not be licensed.

Polmtics of Prostrtution, supra note 4, at 63. 
not provide when it required mandatory sentences. ${ }^{104}$ In practice, therefore, whether or not to include prior convictions in the pleadings has become a factor in the plea-bargaining process, often used to induce defendants not to request costly jury trials. ${ }^{105}$ Finally, masinuch as jail sentences have not produced much in the way of rehabilitation or deterrence, ${ }^{106}$ their continued use on a mandatory basis seems unwarranted.

\section{The Implications of Decriminalization}

Decriminalization of prostitution, even if accompanied by minimal governmental regulation, may not be a palatable alternative to some segments of society. If prostitution is to be eliminated altogether, concerted efforts must be made toward ameliorating the conditions that give rise to prostitution-prevalent attitudes toward sexuality and sexual roles, ${ }^{167}$ race- and sex-based discrimination in employment, and madequate education and job training for women. One step in this direction might be to provide counseling services for prostitutes seeking other alternatives; however, as with drug abusers, a variety of programs with different approaches seems indicated, and those in which former prostitutes play a leading role may prove most effective. ${ }^{168}$ Alternatively, we can accept prostitution as a fact of life and the choice to become a prostitute as an acceptable lifestyle. Many people today, probably a majority, do not see prostitution per se as creating significant harm. ${ }^{100}$

Decriminalization of acts of prostitution and solicitation that take place in private, along the lines of the foregoing proposals, promise to reduce the more abusive aspects of prostitution. The long term effects of such a proposal will not become apparent unless it is tried, and further legislative modifications may be required. The present system of partial and selective enforcement, however, is costly and meffective. A concerted effort at suppression would be far more costly, and seems illadvised given the level of more serious crimes. Reform appears clearly

164. S.F. COMMITIEE oN CRIME, supra note 2, at 25.

165. This information was provided by a San Francisco lawyer who has handled prostitution cases and confirmed by persons who have worked in the San Francisco Public Defender's office.

166. S.F. COMMTITEE ON CRIME, supra note 2, at 26.

167. The Wolfenden Report, supra note 104, at 133, concluded:

Prostitution is an evil of which any society which clains to be civilized should seek to rid itself; but this end could be achieved only through measures directed to a better understanding of the nature and obligation of sexual relationships and to a raising of the social and moral outlook of society as a whole. . . . But until education and the moral sense of the community bring about a clrange of attitude toward the fact of 1rostitution, the law by itself cannot do so.

168. See WINICK, supra note 8, at 289-91.

169. See notes $89-91$ supra and accompanying text. 
indicated, for, as the San Francisco Committee on Crime concluded in unaking similar recommendations, "[w]e can do little worse by trying something different."170

\section{II}

\section{Judicial Protection of Constitutional Rights}

In the preceding section it was argued that legislative reform of the current prostitution law, Penal Code section 647(b), is needed. The legislative process, however, is frequently a lengthy one, particularly when the subject matter is likely to arouse controversy; in the interim, courts will continue to be confronted with the task of applying the existing law. The current law, and particularly the ways in which it is typically enforced, inay infringe on constitutionally protected individual rights in two major respects. First, individual privacy may be unreasonably invaded by the law and its enforcement. Second, selective enforcement of the law directed primarily at prostitutes may violate the equal protection of the laws. The remainder of this Comment will address these two areas, exploring both the nature of the possible infringeinents and the task of fashioning appropriate judicial remedies to protect individual rights.

\section{A. The Right of Privacy}

\section{The Nature of the Right}

The right of privacy emerged as a federally guaranteed right in a series of recent opinions protecting individual autonoiny regarding contraception, ${ }^{171}$ abortion, ${ }^{172}$ and the possession of films and reading inatter regardless of their social worth. ${ }^{173}$ Although soine commentators have seen in the right of privacy a means for preserving "the autonony of one's personality against unreasonable governmental incursions,"174 it

170. S.F. CoMmtrteg on CrIME, supra note 2, at 37.

171. See Griswold v. Connecticut, 381 U.S. 479 (1965), holding that a prohibition on the use of contraceptives is an impermissible violation of inarital privacy; and Eisenstadt v. Baird, 405 U.S. 438 (1972), holding on equal protection grounds that a state may not condition access to contraceptives on inarital status.

172. See Roe v. Wade, 410 U.S. 113 (1973), holding that although states inay reasonably regulate abortion beyond the first trimester to protect maternal health and potential life, to restrict a woman in consultation with a physician from obtaining an abortion in the first trimester invades her right of privacy.

173. See Stanley v. Georgia, 394 U.S. 557 (1969), holding that a prohibition on possession of obscene inaterials in one's home impermissibly invades both individual privacy and first amendinent interests.

174. Hufstedler, The Directions and Misdirections of a Constitutional Right of Privacy, 26 Record of THE Ass'N OF THE BAR OF THE CTTY OF New YoRR 546 (1971); see also Note, Roe and Paris: Does Privacy Have a Principle?, 26 Stan. L. Rev. 1161 (1974); Note, The Constitutional Right of Privacy: An Examination, 69 Nw. U.L. Rev. 
appears unlikely that the right of privacy will be expanded in the foreseeable future to place the private sexual behavior of consenting adults beyond the scope of government regulation. ${ }^{175}$

At the state level the right of privacy is guaranteed to all Californians through a constitutional amendment ${ }^{178}$ affording the state's courts an opportunity to expand the right of privacy on independent grounds. ${ }^{177}$ In White v. Davis, ${ }^{178}$ involving the use of undercover police agents on a university campus, the California Supreme Court issued its first interpretation of the new privacy amendment. Drawing from the arguments advanced by the amendment's proponents, the court concluded that "the amendment does not purport to prohibit all incur-

263 (1974); Note, On Privacy: Constitutional Protection for Personal Liberty, 48 N.Y.U.L. REV. 670 (1973).

175. See Doe v. Commonwealth's Attorney, 96 S. Ct. 1489 (1976), aff'g 403 F. Supp. 1199 (S.D. Va. 1975). The Supreme Court upheld a 3-judge panel's decision that Virginia's sodomy statute was constitutional as applied to consenting adult homosexuals in private. The lower court interpreted previous Supreme Court privacy cases as holding that "the Constitution condeinns State legislation that trespasses upon the incidents of marriage, upon the sanctity of the home, or upon the nurture of family life." $403 \mathrm{~F}$. Supp. 1199, 1200. This restrictive interpretation is open to question. Although dicta in Griswold support state control of consensual sexual behavior, 381 U.S. 479, 499 (Goldberg, J., concurring), the individuals in Roe and Baird were not married, and Baird clearly held that the privacy right in question was an individual right, not an incident of the marital relationship. See note 171 supra. The enforcement of sodomy-or prostitution-laws can trespass on the sanctity of the home: "I view those cases as standing for the principle that every individual has a right to be free from unwarranted governmental intrusion into one's decisions on private matters of intimate concern. A mature individual's choice of an adult sexual partner, in the privacy of his or her own home, would appear to ine to be a decision of the utmost private and intimate concern. Private consensual sex acts between adults are matters, absent evidence that they are harmful, in which the state has no legitimate interest." 403 F. Supp. at 1203 (Merhige, J., dissenting).

176. As revised in 1974, the constitution provides: "All people are by nature free and independent and have inalienable rights. Among these are enjoying and defending life and liberty, acquiring, possessing and protecting property, and pursuing and obtaining safety, happiness, and privacy." CAL. CoNST. art. I, \&1.

177. In recent decisions the California Supreme Court has increasingly relied on independent state grounds. See, e.g., People v. Ramey, 16 Cal. 3d 263, 275-76, 545 P.2d 1333, 1340-41, 127 Cal. Rptr. 629, 636-37 (1976) (prohibiting warrantless arrests in the home); People v. Disbrow, 16 Cal. 3d 101, 113, 545 P.2d 272, 280, 127 Cal. Rptr. 360, 368 (1976) (prohibiting use of statements obtained in violation of the standards declared in Miranda to impeach defendant); People v. Brisendine, 13 Cal. 3d 528, 548, 531 P.2d 1099, 1112, 119 Cal. Rptr. 315, 327-28 (1975) (limiting search incident to arrest disposed of by citation), noted at 64 CalIF. L. Rev. 442 (1976); People v. Anderson, 6 Cal. 3d 628, 493 P.2d 880, 100 Cal. Rptr. 152 (1972) (death penalty constitutes cruel or unusual punishment). See generally Falk, The State Constitution: A More Than "Adequate" Non-Federal Ground, 61 Calur. L. Rev. 273 (1973). Strong dissents to this practice have been registered, particularly in Brisendine and Disbrow.

178. 13 Cal. 3d 757, 533 P.2d 222, 120 Cal. Rptr, 94 (1975), noted at 64 Cal.Ip. L. Rev. 347 (1976). 
sion into individual privacy but rather . . . any such intervention must be justified by a compelling interest." 178

The prostitution law permits incursions into individual privacy in several respects. It infringes on individual choice regarding the exercise of one's sexuality. It further permits surveillance and intrusion of law enforcement officers upon individuals engaged in sexual behavior in private, and permits inquiry into one's intimate activities and the compiling of inforination about those activities. Although the state's interests in protecting the general public against offensive manifestations of prostitution may justify prohibiting acts of solicitation and prostitution that occur in public, it is arguable whether other state interests ${ }^{180}$ are sufficiently compelling to warrant a prohibition on all acts of prostitution and solicitation that occur in private. Based upon the California guarantee of privacy, for example, courts might find that a prohibition extending to acts of solicitation and prostitution that occur in one's lome or apartment imperinissibly intrudes on imdividual privacy, given the greater degree of protection afforded to the home. ${ }^{181}$ Complex interest balancing, however, is involved in any consideration of the prostitution law, a task traditionally left to the legislature. In light of the state supreine court's recent endorsement in the obscenity context of a broad state power to regulate in the interests of maintaining "the quality of life and the total community environment," ${ }^{182}$ a challenge to

179. Id. at 775,533 P.2d at $234,120 \mathrm{Cal}$. Rptr. at 106 .

180. See text accoinpanying notes 26-91 supra discussing the various state interests underlying the law.

181. See, e.g., Stanley v. Georgia, 394 U.S. 557 (1969), holding that states may not prohibit the private possession of obscene materials. In Ravin v. State, 537 P.2d 494 (Alas. 1975), the Alaska Supreme Court held that a law prohibiting possession of marijuana in the houne was an infringennent of the right of privacy protected by both the federal and Alaska constitutions which did not bear a substantial relationship to the state's legitimate purposes in controlling marijuana use. Id. at 511. A similar argument might be made with respcct to soine instances of prostitution. See notes 213-219 infra and accompanying text.

182. Bloom v. Municipal Court, 16 Cal. 3d 71, 82, 545 P.2d 229, 236, 127 Cal. Rptr. 317, 324, quoting Paris Adult Theatre v. Slaton, 413 U.S. 49, $57-63$ (1973). The Supreme Court in Paris deferred to legislative judgments based on "unprovable assumptions about what's good for people," 413 U.S. at 62 , in regulating obscenity by relying on earlier holdings that obscenity is not protected expression. As Justice Brennan pointed out in dissent, however, the Court had not probed the asserted state interests in curtailing sexually oriented expression in Roth v. United States, 354 U.S. 476 (1957). 413 U.S. at 105. The Paris court further justified deferring to state regulatiou of the individual's claim under the right of privacy to watch the films of his choice in a place of public accommodation by confining the right of privacy to a class of protected relationships and the hoine. 413 U.S. at 66 . Thus the Court never conducted an independent review into exactly what the state's interests in prohibiting obscenity are and whether these interests justify the burden on individual autonomy. By deferring to broad and illdefined state interests in maintaining order and morality, the Court in effect deferred on the basic question whether the infringenent of first amendment and privacy interests can be justified-a task that properly belongs to the Court. See Note, 87 Harv. L. REv. $160,174-75$ (1973). 
the validity of the prostitution law on privacy grounds would probably be unsuccessful at the present time.

\section{Privacy and Probable Cause: An Alternative}

The importance to the individual of retaining a measure of privacy and individual autonomy regarding sexual behavior ${ }^{183}$ indicates that governmental intrusions on privacy in this context ought to be subjected to some judicial scrutiny. In privacy cases an available alternative to the compelling state interest test may be the use of the "reasonableness" and "probable cause" limits of the fourth annendment as the criteria for justifiable intrusion. ${ }^{184}$ In general, the compelling state interest test is appropriate for considering the validity of a statute, while tests derived from fourth amendment notions of reasonableness are more appropriate for evaluating the legality of specific governmental acts. The tools developed in the search and seizure context are especially apphicable to the phenomenon of prostitution, whose complexity and variety are not reflected in the broad proscriptions of the current law. Trial judges are already familiar with search and seizure law. Furthernore, that body of law is designed to draw fine distinctions based on particularized facts; therefore, it may be more useful in evaluating whether, in each case, the intrusions on individual privacy are reasonable in light of the harn created by the individual's conduct.

Given the limited extent to which the law actually deters prostitution, perhaps the most significant infringement of imdividual privacy caused by the prostitution law is not its inhibition of freedom of choice, but the intrusive kinds of enforcement to which it exposes individuals who engage in prostitution. This analysis suggests that the role of the courts in protecting individual privacy in this instance lies not so much in enlarging individual freedom by removing the barriers created by the law, as in insuring that the privacy of those against whom the law is enforced is not invaded by unreasonable means. An approach based on fourth amendment concepts, applied on a case-by-case basis to particular facts, would thus seem appropriate in prostitution cases and in some other cases involving the privacy amendinent. ${ }^{185}$

183. The norms of our society dictate that sexual expression must be heavily veiled with secrecy and any governmental action that actually or potentially lifts that veil impairs integrity or personality. The fear of governmental voyeurism is thought to be almost as destructive of personality as would be a physical intrusion.

Hufstedler, supra note 174, at 559.

184. Note, 64 CALIF. L. Rev. 347, 361 (1976).

185. Id. at 363-65. The Note suggests, for example, that the compelling state interest test might be appropriate in considering a financial disclosure law, while many kinds of government surveillance and data-gathering could be evaluated under a flexible fourth amendment standard. 
Such an approach would raise every prostitution case to the level of a constitutional question. The threshhold determinations would be whether the individuals had a reasonable expectation of privacy and whether their conduct in public had given a police officer probable cause to investigate further. Constitutional claims in cases involving blatant street solicitation by customers or prostitutes could be resolved easily. When, however, officers actually intrude upon individuals engaging in prostitution in a place, such as a hotel room, that affords a reasonable expectation of privacy, or when a decoy is sent to invite a solicitation in the privacy of the prostitute's apartment or place of business, the individuals' privacy interests are substantially increased and the governmental interest considerably diminished. What is needed in both cases is a test that balances the nature and magnitude of the individual interests in privacy against the governmental interest that occasions the search. In the former case such a test is available in the notion of probable cause; in the latter instance these concepts may be applied by analogy.

\section{Probable Cause and Police Surveillance}

\section{a. Judicial Applications of Probable Cause}

The development of a "sliding scale" approach to problems presented by police searches, one which graduates the protections of the fourth amendment in proportion to the intrusiveness of the search, has been detected in recent opinions of the United States Supreme Court. ${ }^{180}$ For example, although the Court has permitted pat-down searches of the outer clothing upon a lesser showing of probable cause than would be required for a full body search, ${ }^{187}$ it has also indicated that particularly intrusive searches, such as the extraction of blood samples, require a greater justification..$^{188}$ Califorma courts have expanded on this approach. For example, although the lesser showing required for a stop-and-frisk may justify the stopping of a vehicle for possible traffic violations, an additional showing of specific and articulable facts is required before either the vehicle ${ }^{189}$ or its driver ${ }^{190}$ may be searched for weapons, unless the individual is to be taken into custody. ${ }^{191}$ The

186. Amsterdam, Perspectives on the Fourth Amendment, 58 MiNN. L. Rev. 349, 390 (1974) [hereinafter cited as Amsterdam].

187. Terry v. Ohio, 392 U.S. 1 (1968).

188. Schmerber v. California, 384 U.S. 757 (1966).

189. People v. Superior Court (Kiefer), 3 Cal. 3d 807, 830, 478 P.2d 449, 464, 91 Cal. Rptr. 729,744 (1970).

190. People v. Superior Court (Simon), 7 Cal. 3d 186, 205-06, 496 P.2d 1205, 1219, 101 Cal. Rptr. 887, 851 (1972).

191. People v. Brisendine, 13 Cal. 3d 528, 537-38, 531 P.2d 1099, 1104-05, $119 \mathrm{Cal}$. Rptr. 315, 320-21 (1975). See Note, 64 CaLIF. L. Rev. 442, 443-44 (1976). 
state's interests in police safety that permit the search for weapons do not justify a further search for contraband unless it is based on independent, articulable supporting facts. ${ }^{102}$ In cases involving warrantless searches the California Supreme Court, building on the United States Supreme Court decision in Katz v. United States, ${ }^{103}$ has balanced the individual's expectation of privacy against the reasonableness of the means used by the police in gathernig evidence. Evidence has been suppressed that was gained througl a warrantless search of defendant's trash can, ${ }^{104}$ through eavesdropping on a conversation between defendant and his wife in an office in the police station, ${ }^{105}$ and through clandestine observations in a public restrooin. ${ }^{196}$ Both of these notions-that probable cause is to be adjusted in proportion to the intrusiveness of the search and that individuals' reasonable expectations of privacy are to be protected against unreasonable searches-should be applied to the enforcement of the prostitution law.

\section{b. Surveillance in Prostitution Cases}

The enforcement of the prostitution law by the surveillance method, in which officers follow a suspected couple and listen outside the hotel or motel room or intrude into the roojn itself, ${ }^{197}$ represents a substantial invasion of individual privacy. The intimate nature of the conduct, the individuals' reasonable expectations of privacy, and the minor nature of the offense ${ }^{198}$ suggest that only a strong showing of probable cause should render sucl an intrusion "reasonable."

In Katz v. United States ${ }^{109}$ the Supreine Court noted that

The Fourth Amendment protects people, not places . . . . What a person knowingly exposes to the public . . . is not a subject of Fourth Amendment protection . . . . But what lie seeks to preserve

192. People v. Brisendine, 13 Cal. 3d 528, 543-44, 531 P.2d 1099, 1108-09, 119 Cal. Rptr. 315, 324-25.

193. 389 U.S. 347 (1967) (warrantless eavesdropping on conversation in a public phone booth held to violate the fourth amendment).

194. People v. Krivda, 5 Cal. 3d 357, 486 P.2d 1262, 96 Cal. Rptr. 62 (1971), vacated and remanded for clarification, 409 U.S. 33 (1972), clarified, 8 Cal. 3d 623, 504 P.2d 457, 105 Cal. Rptr. 521 (1973). See also People v. Smith, 52 Cal. App. 3d 514, 125 Cal. Rptr. 192 (2d Dist. 1975).

195. North y. Superior Court, 8 Cal. 3d 301, 502 P.2d 1305, 104 Cal. Rptr. 833 (1972). Because the police had given the couple a reasonable expectation of privacy in allowing them to use the office, the general lack of privacy rights of prisoners was held inapposite.

196. People v. Triggs, 8 Cal. 3d 884, 506 P.2d 232, 106 Cal. Rptr. 408 (1973).

197. See notes 116-19 supra and accompanying text.

198. Prostitution is a misdcmeanor, requiring reasonable cause on the arresting officer's part that the offense has been committed in his presence or the use of an arrest warrant. Cal. Penal CODE $\$ 836$ (West 1972).

199. 389 U.S. 347 (1967). 
as private, even in an area accessible to the public, may be constitutionally protected. ${ }^{200}$

Thus the Court held that eavesdropping by means of an electronic device placed outside a telephone booth in which an individual had an expectation of privacy constituted a search and therefore required a warrant. $^{201}$ In People v. Triggs ${ }^{202}$ the California Supreme Court similarly held that clandestine observations of individuals in public restrooms constituted a search within the meaning of the fourth amendment. ${ }^{203}$ Although the common area of a hotel corridor does not afford an expectation of privacy, the rented rooln itself might be considered analogous to the telephone booth in Katz. ${ }^{204}$ The conduct of officers listening at the keyhole would appear in the light of Katz and Triggs to constitute a search.

Whether officers have probable cause to invade the privacy of a couple in a hotel room, then, must turn on the conduct of the parties prior to entering the room, not what the officers may hear while listening at the door. In Triggs the court held that "arguably suspicious behavior . . . susceptible to an innocent explanation . . . cannot afford the police probable cause to search,"205 noting that "common rumor or report, suspicion, or even 'strong reason to suspect' have been historically inadequate to establish probable cause . . . ."208

A conversation between a man and a woinan on a public street or in an automobile, even when one of them is known or suspected to be a prostitute, is similarly susceptible to innocent interpretation. When the parties attempt to preserve the private nature of the conversation, the logic of Katz suggests that pohice are limited in the use they can make of evidence gaimed through an attempt to overhear the conversation. Without conduct by the parties giving rise to specific and articulable facts strongly indicating a criminal intent, then, any evidence obtained through subsequent eavesdropping at the hotel roon door or through

200. Id. at 351-52.

201. Id. at 353.

202. 8 Cal. 3d 884, 506 P.2d 232, 106 Cal. Rptr. 408 (1973).

203. Id. at 891-92, 506 P.2d at 237, 106 Cal. Rptr. at 413.

204. Similar reasoning was applied in Triggs. There the court noted that police observation of criminal conduct taking place in the common areas of a public restroom does not constitute a search; lowever, clandestine observation of those with a reasonable expectation of privacy is a search within the fourth amendment. Id. at 894, 506 P.2d at 238-39, 106 Cal. Rptr. at 414-15.

205. Id. at $895,506 \mathrm{P} .2 \mathrm{~d}$ at $239,106 \mathrm{Cal}$. Rptr. at 415 , citing Irwin v. Superior Court, 1 Cal. 3d 423, 427, 462 P.2d 12, 14, 82 Cal. Rptr. 484, 486 (1969), and Terry v. Oliio, 392 U.S. 1, 20-22 (1968).

206. 8 Cal. 3d at 895, 506 P.2d at 239, 106 Cal. Rptr. at 415, quoting Henry v. United States, 301 U.S. 98, 101 (1959), and citing People v. Superior Court (Kiefer) 3 Cal. 3d 807, 813-828, 478 P.2d 449, 451-63, 91 Cal. Rptr. 729, 731-43 (1971). 
forcible entry into the room itself would appropriately be suppressed as the "fruits" of an illegal search. ${ }^{207}$ In granting a motion to suppress evidence gamed in circumstances like those related above, a superior court judge recently noted:

The right of privacy is guaranteed to every member of society; even to consenting adults engaging in the most intimate of personal relationships in sordid and perhaps, on a moralistic plane, in reprehensible conduct. The violation of that right dictates the invalidity of the 'search and seizure' within the guarantees of the fourth amendment. ${ }^{208}$

Judicial scrutiny of the circumstances of police surveillance through greater use of the motion to suppress illegally obtained evidence ${ }^{209}$ might afford protection against unreasonably intrusive imvasions of individual privacy. In this way courts might significantly limit the use of the surveillance method. In those cases where the parties clearly bring their intentions to public attention through obvious and aggressive means of solicitation, ${ }^{210}$ an arrest could be made for solicitation. This method of enforcement would lead to a more equitable balancing of individual privacy interests and the public interest in prohibiting disorderly conduct of the kind at which the statute is principally aimed. ${ }^{211}$

207. Nardone v. United States, 308 U.S. 338 (1939).

208. People v. Sullivan, No. 799 (slip op. at 3) (Alameda County Super. Ct., App. Dep't, June 5, 1975).

209. CaL. Penal Code $\$ 1538.5$ (West Supp. 1976) provides that

(a) A defendant niay move for the return of property or to suppress as evidence any tangible or intangible thing obtained as a result of a search or seizure on either of the following grounds:

(1) The search or seizure without a warrant was unreasonable.

(2) The search or seizure with a warrant was unreasonable because (i) the warrant is insufficient on its face; (ii) the property or evidence obtained is not that described in the warrant; (iii) there was not probable cause for the issuance of the warrant; (iv) the method of execution of the warrant violated federal or state constitutional standards; or (v) there was any other violation of federal or state constitutional standards.

210. For example, particularly blatant solicitations, such as repeatedly flagging down motorists or accosting passers-by would constitute probable cause for arrest for solicitation, as would a discussion of price within earshot of the arresting officers. Since, however, noncommercial sexual behavior between adults in private is now legal, probable cause would have to include some evidence that prostitution, rather than simply consensual sexual conduct, had been arranged.

211. Professor Amsterdam has argued that restrictions on the gathering of evidence througl the use of the exclusionary rule have limitations. Amsterdan, supra note 186, at 429-39. He has argued that greater use of administrative rulenuaking would provide more protection against arbitrary searches than the present system of case-by-case adjudication, while providing both courts and police with clearer and nore rcalistic rules. Id. at 416-29. Courts might therefore require prior articulation by police of rules regarding surveillance of individuals in prostitution cases, rather than attempt to formulate policy through ad hoc adjudication. 


\section{Acts of Solicitation in Private}

When the acts of both solicitation and prostitution take place in private, enforcement of the law may impermissibly violate the individual's reasonable expectation of privacy. In this area as well a standard that balances the individual interest and expectation in privacy against the governmental interests underlying the intrusion might afford increased protection for individual privacy in a limited group of cases. In these cases enforcement is typically by the decoy method, in which police officers pose as customers and attempt to invite solicitations. ${ }^{212}$ When solicitation takes place in public places, any individual interest in privacy may be outweighed by the state's interest in prohibiting potentially offensive conduct. In cases where the decoy makes contact with the suspected prostitute in private, particularly when contact occurs in her home or apartment, the individual privacy interest is considerably greater and the state's interest seems considerably diminished. Two approaches are available to the courts to balance the interests in such cases. First, the statute might be construed in light of the greater protection afforded by the recent privacy ainendment. Second, courts can exercise greater supervision over the use of decoys by applying fourth amendment concepts of reasonableness and probable cause by analogy.

\section{a. Construction of the Statute}

Penal Code section 647, enacted in 1961 in place of the former vagrancy law, proscribes a variety of modes of "disorderly conduct."213 In reviewing the need for such a law, Professor Sherry, the original drafter of the section, commented:

The beggar or "moocher" need not and cannot be tolerated in the modern commumity; persons found in public places so intoxicated as to endanger their safety or to be unable to control their behavior must be restrained and protected; the pimp, the panderer and the prostitute cannot be permitted to flaunt their services at large; the lewd and dissolute must be halted when their conduct outrages public decency or threatens harm to the schoolchild; and the loiterer in dark places,

212. See notes 120-24 supra and accompanying text.

213. Ch. 560, $\$ 2$, [1961] Stat. 1672, repealing CaL. Penal Code $\$ 647$ (codified at CaL. Penal CoDe $\$ 647$ (a) (West 1970)) defines as guilty of disorderly conduct every person "[w]ho solicits anyone to engage in or who engages in lewd or dissolute conduct in any public place or in any place open to the public or exposed to public view." In addition to prostitution, section 647 also prohibits (c) public begging, (d) loitering about public toilets, (e) loitering or wandering on public streets with unapparent and unaccountable purpose, (f) public drunkenness, ( $g$ ) prowling on private property, (h) peeping at might into private buildings and (i) lodging without permission in public or private buildings. CAL. PENAL CODE $\$ \S 647$ (c)-(i) (West 1970). 
the Peeping Tom and the prowling trespasser are obvious dangers to the public peace and the safety of persons and property. 214

Unlike the other subdivisions, however, 647(b) would appear to reach conduct that does not take place in public or on the private property of another without permission. Since all other crimes involving prostitution, such as pimping, pandering, procuring, or operating a house of illfame, are separately proscribed in various sections of Title 9 of the Penal Code (Crimes Against the Person and Against Good Morals), ${ }^{215}$ the proscription of prostitution as a mode of disorderly conduct was, as Professor Sherry seems to indicate, arguably intended to reach such conduct only in its overt public nnanifestations. That the legislature did not require that those convicted of violating section $647(\mathrm{~b})$, unlike those convicted of sections 647(a) and (d), register as sex offenders, ${ }^{210}$ lends further support to the conclusion that the legislature was concerned with the potentially offensive nature of public solicitation rather than the "immorality" of prostitution itself. Such an interpretation is consistent with the language of section $64 \%$ (a), which prohibits soliciting and engaging im "lewd or dissolute conduct" in public places, conduct more likely to "outrage public decency"217 or "lead to a breach of the peace."218 It is further consistent with the California Supreme Court's conclusion that "the basic purpose of section 647 is to punish the crime of vagrancy in its various overt aspects."210

This construction of the statute might be used to limit its reach generally to cases where the act of solicitation occurs in public. Alternatively, a court might find that the law as applied in a particular case, particularly when the solicitation takes place in the defendant's residence, is an impermissible intrusion on privacy that does not bear a substantial relationship to the dominant purpose of the statute.

\section{b. Probable Cause and the Use of Decoys}

In holding that warrantless arrests of suspects in their homes in the

214. Sherry, supra note 28, at 566. Although he noted that England's Vagrancy Act of 1824, in contrast to California's, did not punish a prostitute "unless she wandered in the public streets behaving in a riotous or indecent inanner," 48 CALIF. L. REv. at 564 , lie does not explain why the proposed section 647 (b) proscribes nonpublic conduct. In fact, unlike the other provisions, he does not offer any explanation or rationale for section 647(b). See 48 CALIF. L. REv. at 570.

215. This title includes prohibitions against rape, carnal abuse, seduction, obscenity, bawdy louses, and the regulation of alcohol and tobacco. CAL. PENAL CODE \$ 261367 (West 1970). See note 26 supra.

216. Cal. Penal Code $\$ 290$ (West 1970).

217. People v. Mesa, 265 Cal. App. 2d 746, 751, 71 Cal. Rptr. 594, 597 (4th Dist. 1968).

218. Id. at 751, 71 Cal. Rptr. at 598, quoting People v. Dudley, 250 Cal. App. 2d 955, 959, 58 Cal. Rptr. 557, 559 (L.A. Super. Ct. App. Dep't 1967).

219. Barrows v. Municipal Court, 1 Cal. 3d 821, 826, 464 P.2d 483, 486, 83 Cal. Rptr. 819, 822 (1970). The Supreme Court has not construed section 647(b). 
absence of exigent circumstances violates the fourth amendment, the California Supreme Court recently remarked:

An intrusion by the state into the privacy of the hoine for any purpose is one of the inost awesome incursions of police power into the life of the individual. Unrestricted authority in this area is anathema to the system of checks envisaged by the Constitution. It is essential that the dispassionate judgment of a inagistrate, an official dissociated from the 'competitive enterprise of ferreting out crime' . . . be interposed between the state and the citizen at this critical juncture. ${ }^{220}$

When a decoy makes contact with a suspected prostitute as the result, for example, of an informer's tip and arranges to meet her at her residence, his purpose in entering her home is to gather evidence on which to base an immediate arrest. The individual privacy interests in retaining some sanctuary are the same in this case as in cases involving warrantless arrests. Given the magnitude of the intrusion and the limited governmental interest in preventing private solicitations, the same requirement of prior judicial authorization of an arrest warrant would seein to be appropriate. ${ }^{221}$ Where insufficient cause exists to justify the issuance of an arrest warrant for the suspected prostitute's prior acts, judicial authorization might still be required, upon a slightly lesser showing, for intrusion by a decoy.

When police suspicion is based on an informer's tip, the standards developed for the issuance of an arrest warrant require officers to demonstrate both a basis for the inforiner's reliability and the specific facts on which the informer's information is based. Greater weight is given to citizen informants, ${ }^{222}$ permitting investigation on the basis of complaints by neighbors. When the officer's suspicions are aroused by an advertisement in a sexually oriented newspaper, standards similar to those suggested above for surveillance cases might be used. Where the langnage of the advertisement is as consistent with legal conduct as with illegal conduct-that is, where there is no actual reference to moneyprobable cause to investigate further would not seem to exist.

As an additional protection for individual privacy, courts might require some further showing of factors such as complaints by neigh-

220. People v. Ramey, 16 Cal. 3d 263, 275, 545 P.2d 1333, 1340, 127 Cal. Rptr. 629,636 (1976).

221. Information from an informer known to be reliable, or information froin an unknown informer corroborated by other evidence pertaining to the suspect's criminal activity, is required, People v. Fein, 4 Cal. 3d 747, 752, 484 P.2d 583, 587, 94 Cal. Rptr. 607,611 (1971), as well as the factual basis of any informer's belief, People v. Sesslin, 68 Cal. 2d 418, 424-25, 439 P.2d 321, 326, 67 Cal. Rptr. 409, 414 (1968).

222. A lesser showing of reliability is required when citizens volunteer information, as proposed to informers who are virtual police agents. People v. Ramey, 16 Cal. 3d 263, 268-69, 545 P.2d 1333, 1336, 127 Cal. Rptr. 629, 632 (1976); People v. Duren, 9 Cal. 3d 218, 240, 507 P.2d 1365, 1380, 107 Cal. Rptr. 157, 172 (1973). 
bors, prior evidence of coercion, or injury to persons or property before an investigation may be carried into the suspected prostitute's residence. Prior judicial supervision of the use of decoys, with suppression of evidence where the judgment of a magistrate is not sought, would afford individuals increased protection against governmental intrusion. Limiting the use of decoys to cases in which sone showing of specific harm to others is present would further confine the enforcement of the prostitution law to cases in which there is a greater state interest than the enforcement of inorality, and would provide protections to persons who have a reasonable expectation that the privacy of their residence will not be breached without a coinpelling public need. ${ }^{228}$

\section{B. Selective Enforcement of the Prostitution Laws}

The enforcement of Penal Code section 647(b) falls inost heavily on woinen. In San Francisco there were 917 arrests in 1972 for violations involving heterosexual prostitution. Of those arrested 904 were woinen. In 1974 there were 768 such arrests, of which 756 were of women.224 In Oakland there were 873 such arrests in 1973, and women accounted for 785 of these. In 1974 there were 729 such arrests of which 708 were of woinen. ${ }^{225}$ All but a small portion of these arrests involved street solicitations of undercover decoys. ${ }^{228}$

\section{The Defense of Selective Enforcement}

The California Supreme Court recognized selective enforcement of

223. It may be argued that because the decoy's entry is by consent, the subsequent arrest is analogous to seizure of evidence in "plain view" by an officer who has similarly gained entrance by subterfuge. The California Supreme Court, in Mann v. Superior Court, 3 Cal. 3d 1, 472 P.2d 468, 88 Cal. Rptr. 380 (1970), rejected petitioners' claims that marijuana seized in plain view should have been suppressed, stating that consent to enter was invalid only when there had been a positive misrepresentation by officers to conceal their identity. Id. at 9, 472 P.2d at 472, 88 Cal. Rptr. at 384. See People v. Mesaris, 14 Cal. App. 3d 71, 75, 91 Cal. Rptr. 837, 839-40 (2d Dist. 1970). Subsequent cases, such as People v. McCoy, 40 Cal. App. 3d 854, 362-64, 115 Cal. Rptr. 559, 564-66 (2d Dist. 1974), have upheld the entry by subterfuge of an undercover agent to gain evidence to support the arrest of a drug trafficker by agents waiting outside. This holding would appear to need reevaluation in the light of the emphasis in People v. Ramey of the individual's interest in protecting his belongings and his person from warrantless seizure in his home. See 16 Cal. 3d 263, 275, 545 P.2d 1333, 1340, 127 Cal. Rptr. 629, 636 (1976).

224. Record at 70-71, People v. Richardson, No. M48961 (S.F. Mun. Ct., Oct. 4, 1975).

225. Petition for Writ of Prohibition, App. A, at 11, Hartway v. Municipal Court No. 467688-2 (Alameda County Super. Ct., Aug. 21, 1975). In Stockton, California, 95.5 percent of those arrested in 1973 for violations of section $647(b)$ were female. In re Elizabeth G., 53 Cal. App. 3d 725, 729, 126 Cal. Rptr. 118, 120 (3d Dist. 1975).

226. Record at 52, People v. Richardson, No. M48961 (S.F. Mun. Ct., Oct. 4, 1975); Hartway v. Municipal Court, No. 478688-2 (slip op. at 4) (Alameda County Super. Ct., Aug. 21, 1975). 
the law as a defense to a criminal charge in Murguia $v$. Municipal Court. ${ }^{227}$ The consolidated cases involved six defendants, all members of the United Farm Workers, charged with a variety of offenses. ${ }^{228}$ The defendants filed a motion to dismiss the charges, arguing that a deliberate policy of discriminatory enforcement directed at members of the United Farm Workers violated their right to equal protection of the laws and thus barred their prosecution for these offenses. They also sought to discover evidence of such a policy; the case reached the supreme court on appeal from a denial of the discovery motion. The denial was premised on the unavailability of selective enforcement as a defense. Noting that the United States Supreme Court had recognized that a denial of equal protection would result when a criminal prosecution was "deliberately based upon an unjustifiable standard such as race, religion, or other arbitrary classification,"

Neither the federal nor the state Constitution countenances the singling out of an invidionsly selected class for special prosecutorial treatment . . . . If an individual can show that he would not have been prosecuted except for such invidious discrimination against him, a basic constitutional principle has been violated, and such prosecution must collapse upon the sands of prejudice. ${ }^{230}$

Beyond defining "arbitrary as "bear[ing] no rational relationship to legitimate law enforcement interests," the court did not undertake to consider what classifications might appear arbitrary, ${ }^{231}$ nor did it specify the degree of proof necessary to rebut the presumption of reasonableness given to official acts. ${ }^{232}$ It strongly suggested, however, that in the context of a criminal defense, "the People must denionstrate that they have a compelling interest that necessitates the discriminatory enforcement," ${ }^{233}$ noting that a compelling interest in prosecuting crimes would not suffice. ${ }^{234}$

227. 15 Cal. 3d 286, 540 P.2d 44, 124 Cal. Rptr. 204 (1975).

228. The defendants had variously been charged with such offenses as driving without a license in one's possession, malicious mischief, reckless driving, failing to pass another vehicle safely, and willful disobedience of a court order. Id. at 291, 540 P.2d at 47, 124 Cal. Rptr. at 207.

229. Oyler v. Boles, 368 U.S. 448,456 (1962), quoted in $15 \mathrm{Cal} .3 \mathrm{~d}$ at 290,540 P.2d at 46, 124 Cal. Rptr. at 206. Oyler involved a challenge to a habitual criminal statute. The defendant did not allege that the statute was enforced on the basis of an unjustifiable standard, but merely that it was not applied to all who fit within its terms; hence, the Court had no basis for a finding of selective enforcement.

230. 15 Cal. 3d at 290, 540 P.2d at 46,124 Cal. Rptr. at 206.

231. Id. at 302, 540 P.2d at 54, 124 Cal. Rptr. at 214.

232. Id. at 305, 540 P.2d at 57, 124 Cal. Rptr. at 217.

233. Id. at 304, 540 P.2d at 56, 124 Cal. Rptr. at 216.

234. Id. 


\section{Challenging the Rationale of Selective Enforcement}

In People v. Superior Court (Hartway) ${ }^{235}$ the Court of Appeal for the First District recently upheld a superior court dismissal of charges against 62 prostitutes based on a finding of selective enforcement; ${ }^{230}$ similar arguments have been raised in other cases as well. ${ }^{237}$ In reply prosecutors have offered two basic arguments to justify the discriminatory impact of prostitution laws on women. First, they have asserted that women are in fact more likely to solicit customers than their customers are likely to solicit thein. ${ }^{238}$ Second, they claim that concentrating law enforcement on prostitutes rather than customers is reasonable because prostitutes are more visible, are more likely to be continuing offenders, and are the group that profits commercially froin the transaction. ${ }^{230}$ Therefore, it is contended that the class is not "arbitrary" because it bears a "rational relationship to legitimate law enforcement interests."240 Upon closer examination, lowever, neither contention appears to be supported by the available evidence.

Although the first of these propositions-that the prostitute is more likely to solicit than the man-was accepted by the court of appeal in In re Elizabeth $G .{ }^{241}$ in jurisdictions that have experimented with the use of female decoys, defendanis have presented evidence suggesting that male customers are equally prone to initiate solicitations. San Francisco's brief experiment with female decoys illustrates the point. For periods of 2 to 5 hours a female police officer who had been wired for sound stood on various street corners, responding only perfunctorily to men's invitations. One hundred and fifty solicitations were recorded, resulting in over 100 arrests in the 3 months she remained on duty. ${ }^{243}$ By contrast, an undercover inale decoy officer testified to making only two or three arrests of women a week, resulting in the arrest of some

235. 56 Cal. App. 3d 608, 128 Cal. Rptr. 519, (1st Dist.), hearing granted, 58 Cal. App. 3d 67 (1976) (subsequent history table).

236. Id. at 617, $128 \mathrm{Cal}$. Rptr. at 525 .

237. Successful cases include Reimer v. Jensen, No. 455371 (Alameda County Super. Ct., Apr. 1, 1975), and Pcople v. Richardson, No. M48961 (S.F. Mun. Ct., Oct. 4, 1975); an unsuccessful case is In re Elizabeth G., 53 Cal. App. 3d 725, 126 Cal. Rptr. 118 (3d Dist. 1975).

238. See, e.g., In re Elizabeth G., 53 Cal. App. 725, 732, 126 Cal. Rptr. 118, 121 (3d Dist. 1975).

239. See, e.g., People v. Superior Court (Hartway), 56 Cal. App. 3d 608, 616, 128 Cal. Rptr. 519, 524 (1st Dist), hearing granted, 58 Cal. App. 3d 67 (1976) (subsequent history table); Record at 78, 102, People v. Richardson, No. M48961 (S.F. Mun. Ct., Oct. 4, 1975).

240. Murguia v. Municipal Court, 15 Cal. 3d 286, 302, 540 P.2d 44, 54, 124 Cal. Rptr. 204, 214 (1975). Such, apparently, was the finding in In re Elizabeth G., 53 Cal. App. 3d 725, 733, 126 Cal. Rptr. 118, 122 (3d Dist. 1975), although it does not appear that either the trial court or the appellate court questioned these arguments. Id.

241. 53 Cal. App. 3d 725, 733, 126 Cal. Rptr. 118, 122 (3d Dist. 1975).

242. Testimony of Officer Sandra Daly, Record at 112, People v. Richardson, No. M48961 (S.F Mun C. Net 4 1975) 
100 women in $2 \frac{1}{2}$ years of decoy work. ${ }^{243}$ Similarly, in Oakland, two superior court judges found that the proportion of men arrested in decoy cases bore a direct relation to the proportion of total decoy time allotted to female decoys. ${ }^{243}$ These findings suggest that both prostitutes and customers solicit, and therefore in cases involving heterosexual prostitution, the sex of those arrested will reflect policy decisions regarding the use of male and female decoys, as the court noted in Hartway. ${ }^{245}$

Although it can be sliown that women are not necessarily more likely to commit the offense of solicitation than men, it is still arguable that a policy concentrating enforcement against prostitutes is not "imvidious discrimination," but a reasonable employment of scarce police resources. Prostitutes present a more visible target for law enforcement because of their appearance and continuing presence in areas where they ply their trade. Further, because the prostitute has several contacts each evening, her arrest and conviction will theoretically result in a greater decrease in overall criminal behavior than will the arrest and conviction of a customer. In practice, however, resources thus employed are not effective: arrest and even conviction appear to lave little long run deterrent impact on prostitutes. ${ }^{246}$ On the other liand, arrest and the threat of arrest of customers appear to liave a significant impact on reducing the frequency with which customers seek out street prostitutes. $^{247}$

Concentrating enforcement on the prostitute as a "professional profiteer" is another justification for selective enforcement. Although this characterization appears not to be grounded in sex distinctions, the reahities of heterosexual prostitution insure that a policy directed at the "sellers" will effectively immunize the male customer from prosecution. Both parties "profit" from the transaction, or it would not occur with such frequency; moreover, the statute does not suggest any imtention to punish the seller and not the buyer. That the statute was drafted in

243. Id., Record at 167,185 . These figures may be influenced by the greater number of customers as opposed to prostitutes.

244. People v. Superior Court (Hartway) 56 Cal. App. 3d 608, 613-14, 128 Cal. Rptr. 519, 522 (1st Dist.), hearing granted, 58 Cal. App. 3d 67 (1976) (subsequent listory table); Reimer v. Jensen, No. 455371 (slip op. at 3) (Alameda County Super. Ct., Apr. 1, 1975).

245. 56 Cal. App. 3d at 614, 128 Cal. Rptr. at 522-23.

246. See notes 111 \& 112 supra and accompanying text.

247. See note 103 supra and accompanying text. San Francisco's use of female decoys appeared to lave significant results in reducing prostitution in a residential neighborhood while the program was in operation, Reeord at 60,127, People v. Richardson, No. M48961 (S.F. Mun. Ct., Oct. 4, 1975) (testimony by Captain Shaughnessy and Officer Sandra Daly). Similar experience was reported in Oakland following publicity of Judge Avakian's ruling in Reimer v. Jensen, No. 455371 (Alameda County Super. Ct, Apr. 1, 1975), that equal enforcement was required. (Interview with Spurgeon Avakian, Alameda County Superior Court Judge, in Oakland, Jan. 29, 1976). 
terms that would apply equally to both suggests a legislative intent that the law be enforced with soine degree of equality. As one court recently noted,

The legislative purpose in proscribing solicitation for prostitution is to eliminate prostitution and its attendant evils. Subjecting the customer to prosecution will further the legislative purpose-probably inore so than any other legislative remedy. ${ }^{248}$

Thus a law enforcement policy directed at prostitutes rather than customers cannot be justified as a more effective ineans of furthering the purposes of the statute. Moreover, as the court of appeal observed in Hartway, it results in discrimination on the basis of sex, an arbitrary standard within the meaning of Murguia, and one whicl cannot be justified by any compelling state interest. ${ }^{249}$

The standards announced in Murguia require one asserting the defense of selective enforcement to demonstrate an intentional and purposeful policy of selective enforcement based upon an arbitrary classification. ${ }^{280}$ The Hartway court based its finding of selective enforcement on two factors: first, the substantial imbalance in arrest statistics; and second, extensive testimony both by the commander of the vice squad and several of his officers and by prostitutes and customers regarding policies and practices of the police department. This evidence "established that the prosecuting authorities, in administering the statute, have followed an enforcement pattern deliberately based upon an unjustifiable standard, and that a denial of equal protection has been demonstrated."251

The contrary result in Elizabeth $G$. was reached on the basis of a less complete record. It was apparently also based on a narrow interpretation of Murguia, one which would have required the defendant to establish that she would not have been arrested "except for such invidious discrimination."252 Such a reading, applied literally, would confine

248. Leffel v. Municipal Court, 54 Cal. App. 3d 569, 576, 126 Cal. Rptr. 773, 777 (5th Dist. 1976) (holding that section 647(b) applied to customers as well as prostitutes).

249. 56 Cal. App. 3d at 617, 128 Cal. Rptr. at 525. That a policy of arresting only prostitutes reflects discrimination based on sex was recognized by another jurisdiction over 55 years ago:

The men create the market and the women who supply the deinand pay the penalty. It is time that this unfair discrimination and injustice should cease .... The practical application of the law as heretofore enforced is an unjust discrimination against women in the matter of an offense which in its very nature, if completed, requires the participation of men.

People v. Edwards, 180 N.Y.S. 631, 634-35 (N.Y. County Ct. 1920).

250. $15 \mathrm{Cal}$. 3d at 290, 540 P.2d at 46, 124 Cal. Rptr. at 206.

251. $56 \mathrm{Cal}$. App. 3d at 617, $128 \mathrm{Cal}$. Rptr. at 525. 1975).

252. In re Elizabeth G., 53 Cal. App. 725, 733, 126 Cal. Rptr. 118, 122 (3d Dist. 
the defense of selective enforcement to a relatively small number of defendants; however, the court stated in Murguia that authorities may not enforce a statute fair on its face im a manner that invidiously affects only an arbitrarily selected group. ${ }^{263}$ Where the evidence supports such a finding, as it did in Hartway, the individual defendant would seem to have met her burden of proof.

\section{Remedies}

If the defense of selective enforcement is successfully raised, what judicial remedy should follow such a finding? Murguia indicates that when successful, the defense is a bar to prosecution. ${ }^{254}$ In addition, correcting patterns of selective enforcement in particular communities may require further judicial remedies. For example, in a taxpayers' suit challenging the validity and enforcement of section $647(\mathrm{~b}),{ }^{255}$ the court, after finding a pattern of selective enforcement on the part of the police, issued an injunction that, upon revision, prohibited the use of male decoys "for an aggregate number of hours in any calendar month which exceeds by 25 percent or more the aggregate number of hours in which female decoys are used in the same month."258 Additionally, it enjoined the subjecting of women to custodial arrest as opposed to citations without a written policy requiring that men arrested for a violation of the same offense also be subjected to custodial arrest. ${ }^{257}$ Although such an injunction requires judicial supervision of a city's police department to some extent, ${ }^{258}$ the propriety of imjunctions as a means of restricting discriminatory enforceinent of an otherwise valid statute has been upheld by the California Supreme Court, ${ }^{259}$ as has been the enjoining of the application of constitutionally invalid statutes. ${ }^{280} \mathrm{~A}$ properly drawn injunction, one providing clear guidelines for law enforcement, would seem therefore to be an effective means of imsuring the equal application of the laws where a pattern of discriminatory enforcement can be proven.

253. 15 Cal. 3d at 296, 540 P.2d at 50, 124 Cal. Rptr. at 210. See Yick Wo v. Hopkins, 11.8 U.S. 356 (1886) (denial of laundry permits to all applicants of Chinese ancestry held a violation of equal protection).

254. 15 Cal. 3d at 290, 540 P.2d at 46, 124 Cal. Rptr. at 206.

255. Reimer v. Jensen, No. 455371 (Alameda County Super. Ct., Apr. 1, 1975).

256. Id., Revised Preliminary Injunction at 2 (Dec. 18, 1975).

257. Id.

258. The order further requires monthly statistical reports describing the enforcement of section 647 (b). Id.

259. Brock v. Superior Court, 12 Cal. $2 d 605,610,86$ P.2d 805, 807 (1939) (upholding an injunction against allegedly unconstitutional application of a statute controlling intrastate marketing of agricultural products).

260. Conover v. Hall, 11 Cal. 3d 842, 850, 523 P.2d 682, 686-87, 114 Cal. Rptr. $642,646-47$ (1974) (enjoining enforcement of a state welfare law inconsisteut with federal law). 


\section{Conclusion}

Although the state may legitimately assert certain interests in controlling prostitution, those interests do not justify the proscription of all acts of prostitution and solicitation. Rather, the law should be confined to regulating prostitution and sohcitation to minimize its deleterious impact on the public at large. Moreover, those legitimate state interests do not justify all the ineans by which the present law has been enforced; enforcement methods that result in unreasonable intrusions into individual privacy or selective enforcement of the law should be subjected to judicial control. Where necessary, judicial supervision of law enforcement should be directed at confining enforcement to situations in which public solicitation occurs, and this enforcement should be directed at botli the customer and the prostitute.

Although prostitution will probably never be eliminated through the criminal law, it is incumbent upon both the legislature and the courts to ensure that what laws we have are both fair and fairly enforced. 